\begin{tabular}{llllllllllllllllllllllllllll}
\hline A & C & T & A & A & R & C & H & A & E & O & L & O & G & I & C & A & C & A & R & P & A & T & H & I & C & A
\end{tabular}

\begin{tabular}{lr} 
VOL. LV (2020): 305-342 & PL ISSN 0001-5229 \\
\hline
\end{tabular}

DOI 10.4467/00015229AAC.20.012.13517

\author{
JoAnNa A. Markiewicz
}

\title{
FAMILIARISING THE LANDSCAPE: THE DEVELOPMENT OF PREHISTORIC SETTLEMENT IN THE MIDDLE DUNAJEC River VALLEY
}

\begin{abstract}
Despite the continuous increase of archaeological data coming from the Polish Western Carpathians, the colonisation process of the Beskidy Mountains in prehistory is still relatively poorly recognized. The subject of discussion is, in particular, the impact of environmental and cultural factors on the formation of settlement networks in individual periods. This paper considers these questions on the example of a part of the middle Dunajec River basin in the chronological framework from the Neolithic to the La Tène period. Based on the archaeological and paleoenvironmental record, an analysis of settlement dynamics in terms of preferences and economy in the subsequent periods was carried out. The observations made were then interpreted in the context of cultural phenomena. A comparison of the results with the situation observed in other Central European mountain ranges made it possible to formulate some universal tendencies in the settlement development in these zones. In particular, the impact of climate and environmental conditions on the economy was considered, as well as the role of natural resources and communication routes. It has been demonstrated that three main stages can be distinguished in the process of prehistoric mountain colonisation. This mechanism was correlated with the gradual adaptation of the economy and the "familiarising" of the mountain landscape, which offered both some limitations and strategic values determining the specific cultural function of these areas.
\end{abstract}

Keywords: Dunajec River, mountain colonisation, mountain economy, settlement preferences, Western Carpathians

\section{INTRODUCTION}

The Central European mountains were for a long time perceived by archaeologists as marginal areas of prehistoric human activity. This claim was justified on the one hand by the small number of discovered archaeological sites and artefacts a fact which was mostly the consequence of technical difficulties in conducting research - and on the other by the "commonsense" assumption that both the alpine landscapes and the forest mid-mountains discouraged settlers as geographical

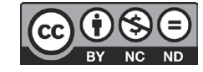


barriers with very low economic potential (Żaki 1963; Della Casa, Walsh 2007). Nowadays there is no doubt that these areas were penetrated and inhabited by humans since the oldest periods of prehistory, and they often played a major role in the transregional cultural transmission. However, the relatively poor state of research on the prehistory of these regions remains an important problem. In the Polish part of the Western Carpathians, the picture of past settlement usually consists of single, often multicultural sites, which, due to their location on specific terrain forms, have not been destroyed by modern buildings. For this reason, it is very difficult to capture some trends in the settlement dynamics over longer periods. The role of environmental and cultural factors in the process of colonisation of this zone is also debatable.

This article is an attempt to trace the development of prehistoric mountain settlement on the example of the middle Dunajec River basin area, which has been relatively well-recognized archaeologically through intensive surface surveys. The adopted chronological framework is marked by the beginnings of the development of the first Neolithic cultures and by the end of the La Tène period around the $\mathrm{BC} / \mathrm{AD}$ transition. The observations regarding settlement structures and preferences in the subsequent phases will be interpreted in the context of local and regional environmental and cultural conditions. A comparison of the results of these analyses with the situation in other European mountains will allow indicating some universal regularities in the process of colonisation of these areas in prehistory. I will try to demonstrate that this mechanism was associated with gradual "learning" of the landscape - at first, the zones most environmentally similar to the foothills were inhabited; only later did the settlers begin to exploit the special qualities of the mountain terrain, which stimulated the expansion of the ecumene and the final breaking of this geographical barrier.

\section{GEOGRAPHICAL AND ENVIRONMENTAL CONTEXT}

The analysed area is situated in the northern part of the Western Carpathians and encompasses a 35-kilometre long section of the middle Dunajec River valley, reaching the northern foothills of the Pieniny Mountains in the south and the southern outskirts of the Sacz Basin and the lower course of the Poprad River in the northeast. The river separates several ranges of the Western Beskidy Mountains in this section: the Gorce Mountains in the west, the Radziejowa Range of the Beskid Sądecki Mountains in the east and the Beskid Wyspowy Mountains in the north. At the junction of these three physiographic units, the Dunajec River valley broadens into the Eacko Basin. The exact borders of the analysed territory are determined by the range of six areas surveyed under the Polish Archaeological Record research program (Archeologiczne Zdjęcie Polski - AZP; Fig. 1). 

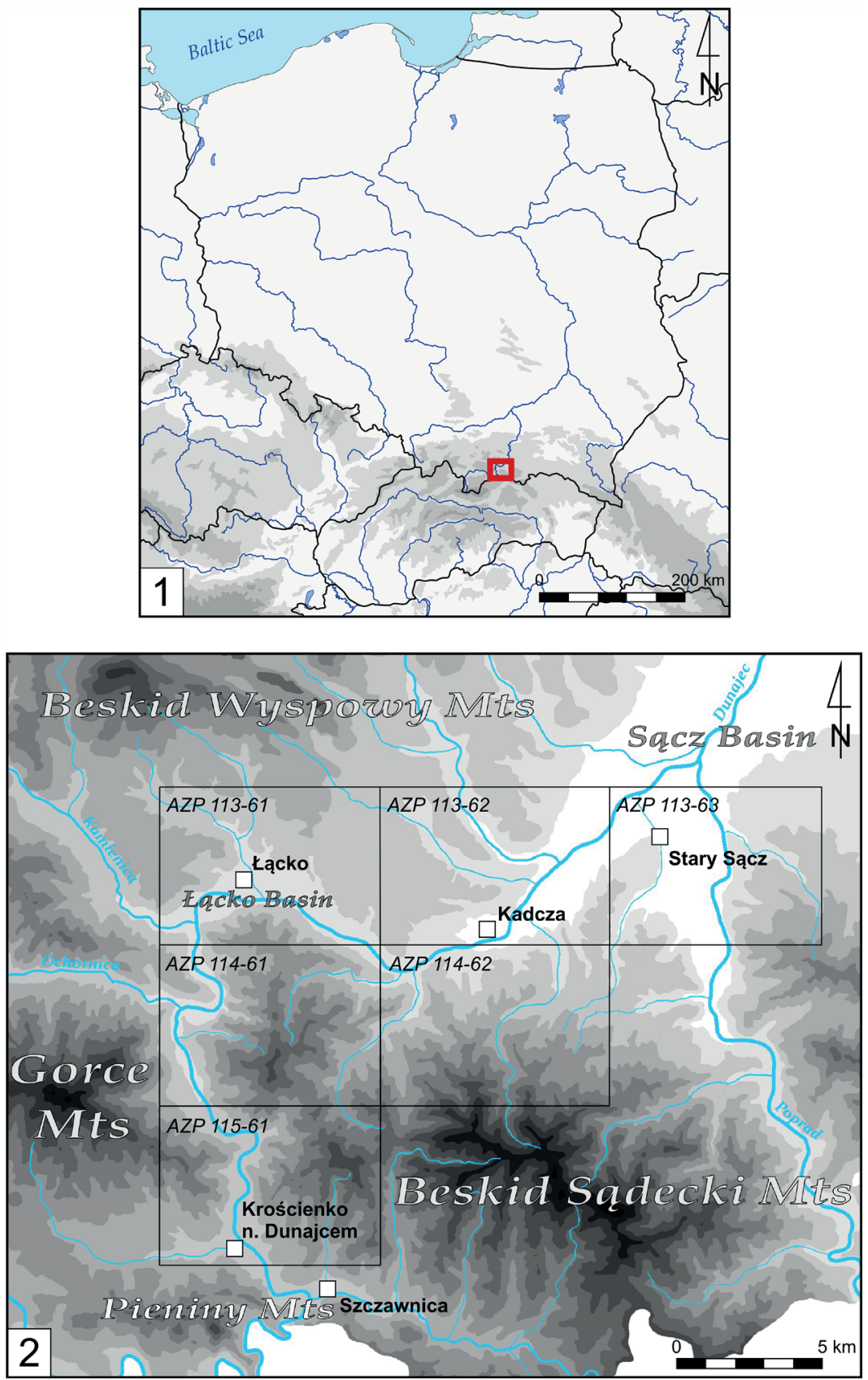

Fig. 1.1 - Location of the analysed area; 2 - borders of the analysed AZP areas in the middle Dunajec River basin; drawn by the author 
The landscape within this relatively small territory is varied. The bottom of the Dunajec River valley falls from a height of approx. $400 \mathrm{~m}$ a.s.l. at the foot of the Pieniny Mountains to approx. $300 \mathrm{~m}$ a.s.l. in the Sacz Basin; the highest elevations within the analysed area reach about $800 \mathrm{~m}$ a.s.l. The southern section of the valley is surrounded by the steep slopes of the high ranges of the Gorce Mountains and the Beskid Sądecki Mountains, which are cut by narrow and deep side-stream valleys. Such terrain relief contributes to the phenomenon of temperature inversion and shallow cold air stagnation, especially in the northern foreland of the Pieniny Mountains. The climate in the valleys is moderate or moderately cold with an average annual precipitation of approx. 700-800 mm and a relatively short growing season (Obrębska-Starklowa et al. 1995). Similar though slightly milder climatic conditions prevail in the northern part of the analysed area, which is dominated by the extensive river terraces, wide side valleys and lower ranges of the Beskid Wyspowy Mountains and Beskid Sacecki Mountains.

The greater part of the territory in question is characterized by unfavourable soil conditions for agriculture. On the hills of the Western Beskidy Mountains, which were originally covered with forest, difficult-to-cultivate Dystric Cambisols developed; more agriculturally valuable, although sometimes also problematic to cultivate, Stagnic Luvisols occur only on the lower, milder hills of the Beskid Wyspowy Mountains, adjacent to the Sacz Basin. The most fertile alluvial soils (Fluvisols) cover the Dunajec and Poprad River terraces, as well as the bottom parts of some wider side valleys (Skiba 1995). These zones were undoubtedly most in demand amongst the prehistoric farmers. The extensive Pleistocene terraces are characterized by special agricultural values, since, unlike the lower Holocene terraces, they are rarely flooded and due to their low slope gradient, they are marginally susceptible to erosion processes (Przybyła, Korzeń, Moskaldel Hoyo 2020).

The analysed area is dominated by lower montane zone vegetation, with Carpathian beech forest and spruce/spruce-fir forests. Only the terraces of major rivers and to some extent the bottom parts of side valleys and lower hillsides are covered in natural conditions with riparian and hornbeam-oak forests (Towpasz, Zemanek 1995). At present, we have a relatively small amount of data referring to the local vegetation in prehistory. Palynological research conducted in the 20th century near the southern borders of the territory in question provided only one profile covering the considered period. A core sample from a peat bog on the north-western slope of Mt. Bryjarka, situated north of Szczawnica, made it possible to reconstruct the history of local vegetation from the late Pleistocene to modern times, but the results of the analysis are strongly distorted by local factors, namely the dense spruce forest cover, which disturbed the pollen fall. The first indicators of human activity were recorded at the early Subboreal 
level, where the pollen of synanthropic Plantago lanceolata appeared. During the early Subatlantic period, the presence of Cerealia marked faintly, but it was not accompanied by other anthropogenic indicators. A radical change of local vegetation, caused by deforestation of the area, occurred only in the younger part of the Subatlantic, outside the chronological range covered by this analysis (Pawlikowa 1965).

A similar rhythm of vegetational changes with supposed human impact indicators at the level of the Subboreal period and permanent anthropogenic transformations since the beginning of the Subatlantic has also been registered in the neighbouring regions: in the Beskid Wyspowy Mountains, the Beskid Makowski Mountains and Podhale Basin (Koperowa 1961; Obidowicz 1990; Margielewski, Zernitskaya 2003; Czerwiński et al. 2019). In the upper section of the Ochotnica River valley, deep in the Gorce Mountains, the human impact on the local environment did not manifest before the Middle Ages (Bucała et al. 2014).

Interesting results were brought by the analysis of the palynological profile from the Zbludza site, located on a hillside above the left tributary of the Kamienica River, a few kilometres northwest of the Łącko Basin (Korzeń 2017; Przybyła, Korzeń, Moskal-del Hoyo 2020). The core sample provided insight into the changes of the vegetation in the Kamienica River valley and the Gorce Mountains within a timespan from the Atlantic period until the modern period. Human impact on the local environment manifested as early as the Neolithic (ca. 5500-4800 BC) through the presence of Cerealia pollen and an increase of herbaceous plants; somewhat earlier the synanthropic Plantago appeared. Subsequent episodes of evident anthropopressure, marked by similar pollen indicators, were recorded in the Early and Middle Bronze Age (ca. 1690-1450 BC) and in the Iron Age (ca. 550-150 BC). In the latter case, it was also found that the cause of the registered deforestation was fires. The thesis of an anthropogenic initiation of these phenomena can be supported by the finds of pottery fragments from this period, discovered on the other side of the Zbludza River valley, opposite the paleobotanical site (Przybyła, Markiewicz 2020).

Some insight into the local vegetational changes was gained as a result of archaeological excavations of the Bronze and Iron Age site on Zyndram's Hill at Maszkowice, which is situated at the northern edge of the Eacko Basin. Based on the analysis of plant macro-remains, it was determined that the surroundings of the Early Bronze Age hillfort were dominated by thermophilous oak forests. In the Late Bronze Age and the Early Iron Age, the forest cover was significantly thinned as a consequence of human activity (Przybyła, Korzeń, Moskal-del Hoyo 2020).

Studies of landslide areas in the nearby Beskid Makowski Mountains and Beskid Wyspowy Mountains provided data on regional climate fluctuations during the Holocene. Within the timespan analysed in this paper, at least six significant episodes of escalation of mass movements were noted, which were 
the result of short-term climate moistening (ca. 5000-4400 BC, 3900-3400 BC, 2800-2600 BC, 2200-2000 BC, 1700-1300 BC, 800 BC-BC/AD transition). These phases are considerably correlated in time with similar phenomena recorded in other European mountains (Margielewski 2006).

\section{STATE OF RESEARCH}

Although the history of research on the prehistory of the Polish Western Carpathians is extensive, the interest of archaeologists rarely reached the mountainous zone; for a long time, the attention was focused on the foothills and depressions. However, the development of interdisciplinary field research in recent years has contributed to better recognition of some areas. Apart from the analysed section of the middle Dunajec River basin, especially the eastern part of the Polish Carpathians (e.g. Machnik, Mačala 2001; Pelisiak 2013) and the Beskid Śląski Mountains region (e.g. Choraży, Chorąży 2015) should be mentioned. At the same time, the collection of theoretical studies on the colonisation of these areas in prehistory, apart from a small number of synthetic reviews, consists mainly of comments made on the margins of reports on new finds. The main topics of discussion are the questions of pastoral exploitation of the mountainous zones (e.g. Valde-Nowak 1988; 1999; Tunia 1989; Machnik 2001; Pelisiak 2013), the communication and defence functions of upland settlements (e.g. MadydaLegutko 1995; Gedl 1998; Chorąży, Chorąży 2015), as well as the role of the Western Carpathians in the interregional cultural contacts (e.g. Czopek, Kadrow 2001; Czopek 2005).

The first archaeological discoveries in the Dunajec River valley were made by chance as early as the 19th century (Morawski 1863; Żurowski 1927). In the 1950 s and 1960s, the area was covered by the prospection of the Carpathian Archaeological Expedition led by A. Żaki; intensive archaeological research was also conducted by M. Cabalska. Excavations were carried out at that time, among others, at Maszkowice, Naszacowice, Podegrodzie, Stary Sącz and Zabrzeż (e.g. Żaki 1954; 1964; Trzepacz-Cabalska 1959; Woźniak 1962; Cabalska 1963; 1965). In the 1970s, during systematic surface surveys conducted by K. Tunia, a number of new archaeological sites in the Poprad River basin were identified (Tunia 1977). In the 1980s and 1990s, the activity of researchers was concentrated mainly in the vicinity of the Sacz Basin, where i.a. traces of the Hallstatt and La Tène period settlements were registered (e.g. Madyda-Legutko, Tunia 1985; Jodłowski 1988; Madyda-Legutko, Poleski 1995). Since 2010, excavations are being conducted under the direction of M. S. Przybyła at the site on Zyndram's Hill at Maszkowice (Przybyła, Skoneczna 2011; 2014; Przybyła 2016; Przybyła, Jędrysik 2017). In 2017, a small sondage was carried out at the "Babia Góra" site 
at Zabrzeż (Jędrysik 2018; Jędrysik et al. in print). The majority of archaeological sites in the analysed territory have been recognized only by surface surveys, most of all during the Polish Archaeological Record (AZP) research program. The areas covered by this analysis were examined under the direction of Krzysztof Tunia (AZP areas 113-62, 113-63, 114-61, 114-62), Andrzej Cetera (113-61) and Elżbieta Dubis (115-61); the documentation also includes results of the previous surveys carried out by the Polish-Slovak team led by P. Valde-Nowak in $1998 .{ }^{1}$ Additional field prospection of the middle Dunajec River valley was conducted under the direction of M. S. Przybyła in 2011, 2016 and 2017; an accidental discovery of an Early Iron Age site was also made in 2018 (Przybyła, Skoneczna 2014; Przybyła, Markiewicz 2020).

\section{METHODS}

The following analysis includes all the archaeological sites within the AZP areas mentioned above, dating from the Neolithic to the BC/AD transition. At this point, some limitations of interpretation arising from the specific source base should be noted. Up to $95 \%$ of the sites recorded in this region were identified only by surface surveys. Conducting this type of field research in the Beskidy Mountains is much more challenging because today these areas are covered mostly with forests, meadows and pastures. Considering the slope processes and a limited ground observation, the number of artefacts on the surface may not proportionally reflect the extent and thickness of the underlying cultural layers. For this reason, the qualitative classification of surface sites based on the number and dispersion of artefacts was not applied. It should be also emphasized that a settlement analysis carried out on the basis of surface sites is at higher risk of error, and observations and conclusions should be formulated in terms of general trends.

In order to apply uniform criteria for determining the chronology of artefacts, all materials from surface surveys, including AZP, were examined. ${ }^{2}$ Pottery fragments were generally non-characteristic and poorly preserved, which significantly hindered their dating. Based on technological features, by comparing to well-dated materials from the excavated sites at Maszkowice and Zabrzeż, they were assigned to several chronological phases: Neolithic (ca. 5500-4000/3500 BC), Eneolithic (ca. 4000/3500-2200 BC), Early and Middle Bronze Age (ca. 2200-1300 BC), Late Bronze Age and Early Iron Age (including the beginnings

\footnotetext{
${ }^{1}$ Archives of the Provincial Office for Monuments Protection in Kraków.

${ }^{2}$ I would like to thank Dr. Krzysztof Tunia for kindly making available for analysis the materials from AZP research.
} 
of La Tène period: ca. 1300-400/300 BC) and La Tène period (ca. 400/300 BC$\mathrm{BC} / \mathrm{AD}$ transition). In the case of strongly damaged or non-characteristic sherds, which were associated with wider periods, the probability of dating a given site to the shorter phases was estimated using so-called fuzzy logic ( $c f$. e.g. Nakoinz 2012). An analogous method was applied to flint artefacts. However, it should be noted that determining the approximate chronology of this category of artefacts (e.g. Stone Age, Younger Stone Age or Bronze Age) on the basis of typological and technological traits was possible only in some cases of tool forms and cores.

As a result of the examination, a database of 340 sites dating from the Neolithic to the BC/AD transition was created (Table 1).

The surface sites with pottery fragments showing technological traits typical of Neolithic "Danubian" cultures (poor firing, dominance of organic admixture in pottery mass) were mainly attributed to the Neolithic. It was not possible to indicate flint inventories as certainly dated to this phase. At the slightly more

Table 1. Number of archaeological sites from each chronological period in the middle Dunajec River basin

\begin{tabular}{|c|c|c|c|c|}
\hline \multirow{2}{*}{ Chronology } & \multirow{2}{*}{ Site type } & \multicolumn{3}{|c|}{ Number of sites (\% of all sites) } \\
\hline & & $\begin{array}{c}\text { probability } \\
100 \%\end{array}$ & $\begin{array}{c}\text { probability } \\
\mathbf{5 0 \%}\end{array}$ & $\begin{array}{c}\text { probability } \\
<50 \%\end{array}$ \\
\hline \multirow{2}{*}{ Neolithic } & surface pottery fragments & $10(2,9 \%)$ & $11(3,2 \%)$ & $11(3,2 \%)$ \\
\hline & surface flint artefacts & 0 & $12(3,5 \%)$ & $34(10 \%)$ \\
\hline \multirow{2}{*}{ Eneolithic } & surface pottery fragments & $22(6,5 \%)$ & $8(2,4 \%)$ & $9(2,7 \%)$ \\
\hline & surface flint artefacts & $6(1,8 \%)$ & $10(2,9 \%)$ & $28(8,3 \%)$ \\
\hline \multirow{2}{*}{$\begin{array}{l}\text { Early and Middle } \\
\text { Bronze Age }\end{array}$} & $\begin{array}{l}\text { settlement/surface pottery } \\
\text { fragments }\end{array}$ & $10(2,9 \%)$ & $8(2,4 \%)$ & $12(3,5 \%)$ \\
\hline & surface flint artefacts & $11(3,2 \%)$ & $19(5,6 \%)$ & $15(4,4 \%)$ \\
\hline \multirow{2}{*}{$\begin{array}{l}\text { Late Bronze Age } \\
\text { and Early Iron Age }\end{array}$} & $\begin{array}{l}\text { settlement/surface pottery } \\
\text { fragments }\end{array}$ & $87(25,6 \%)$ & $76(22,4 \%)$ & $7(2,1 \%)$ \\
\hline & surface flint artefacts & 0 & $4(1,2 \%)$ & $4(1,2 \%)$ \\
\hline La Tène period & $\begin{array}{l}\text { settlement/surface pottery } \\
\text { fragments }\end{array}$ & $7(2,1 \%)$ & 0 & 0 \\
\hline \multirow{2}{*}{$\begin{array}{l}\text { undefined } \\
\text { chronology } \\
\text { (prehistory) }\end{array}$} & surface pottery fragments & & & $4(1,2 \%)$ \\
\hline & surface flint artefacts & & & $150(44,1 \%)$ \\
\hline
\end{tabular}


numerous Eneolithic sites pottery sherds were found with features that could suggest their relationship with the youngest groups of the Lengyel-Polgar circle or the Funnel Beaker culture (relatively soft sherds; smooth, light brown or reddish surfaces, dark grey or black interior; dominance of chamotte as admixture in pottery mass, less frequent mineral or organic admixture). Flakes and shards from polished flint axes were also attributed to this phase. The Early and Middle Bronze Age is represented by one fortified settlement (Zyndram's Hill at Maszkowice) and several surface sites. The distinguished pottery fragments have features characteristic of the materials from the aforementioned excavated site or of the vessels of the Pleszów group of the Mierzanowice culture. Among flint artefacts, several distinctive notched and core tools were attributed to this phase. The largest number of sites was assigned to the Late Bronze Age and Early Iron Age (over 25\% of all registered points), including two hillforts (Zyndram's Hill at Maszkowice and "Babia Góra" at Zabrzeż) and six other excavated settlements ("Jeżowa Góra" and "Kapliczka" at Łącko3; "Zamczysko" at Naszacowice; "Grobla" at Podegrodzie; site 1 and site 40 "Lipie" at Stary Sacz). Although the pottery from these sites can be dated more precisely on the basis of formal and stylistic features, it is practically indistinguishable in terms of technology ( $c f$. Przybyła 2020; Przybyła, Markiewicz 2020). For this reason, these sites were included in the analysis in a wider period. Pottery sherds of technology typical of the materials from the abovementioned settlements were discovered at several dozen surface sites; in the case of a few dozen more, the poor state of preservation of artefacts did not allow us to conclude whether they should be associated with the discussed phase or with the Roman period (dating probability 50\%). In the considered area, only a few sites were registered that can be assigned to the late La Tène period: three excavated settlements (Zyndram's Hill at Maszkowice; "Grobla" at Podegrodzie; "Babia Góra" at Zabrzeż) and two surface sites with, among others, fragments of graphite pottery. For the analysis, two more wellrecognized sites were included in the list (site 9 and "Zamczysko" at Podegrodzie; Madyda-Legutko, Tunia 2015 - further literature there), which are situated just outside the northern borders of the AZP areas in question. To the "prehistory" category, over 150 surface sites were assigned, at which artefacts (mostly flints) of undefined chronology were found.

The sites of different degrees of dating probability are distinguished on the maps by signature size. Discoveries of hoards and single finds (stone and metal artefacts) are indicated on the figures as well (Figures 2-6).

${ }^{3}$ Unpublished materials from the sondage conducted by M. Cabalska in 1960 at "Kapliczka" site and by M. S. Przybyła, J. Jędrysik and R. Kałuziński in 2018 at "Jeżowa Góra" site are deposited in the Institute of Archaeology of the Jagiellonian University in Cracow. 


\section{ANALYSIS}

Spatial distribution of sites - settlement networks

In the analysed area, several zones in which archaeological sites are grouped can be identified. The first zone encompasses the southern outskirts of the Sacz Basin; the second covers the widening of the Dunajec River valley around Kadcza village and the adjacent hills and ranges. The Łacko Basin constitutes a separate settlement zone, which is separated from the previous one by a narrowing of the Dunajec River valley. The last zone extends along the longitudinal course of the Dunajec River, with a narrow valley surrounded by high ranges of the Gorce Mountains and the Beskid Sadecki Mountains. The southernmost part of the analysed area is almost devoid of traces of prehistoric settlement: only a handful of non-characteristic flint artefacts was found during the surface surveys.

Most of the Neolithic sites were registered in the second of these zones (Fig. 2). The settlement traces of undoubtable chronology are situated on the gentle slopes and culminations of hills on both sides of the Dunajec River valley,

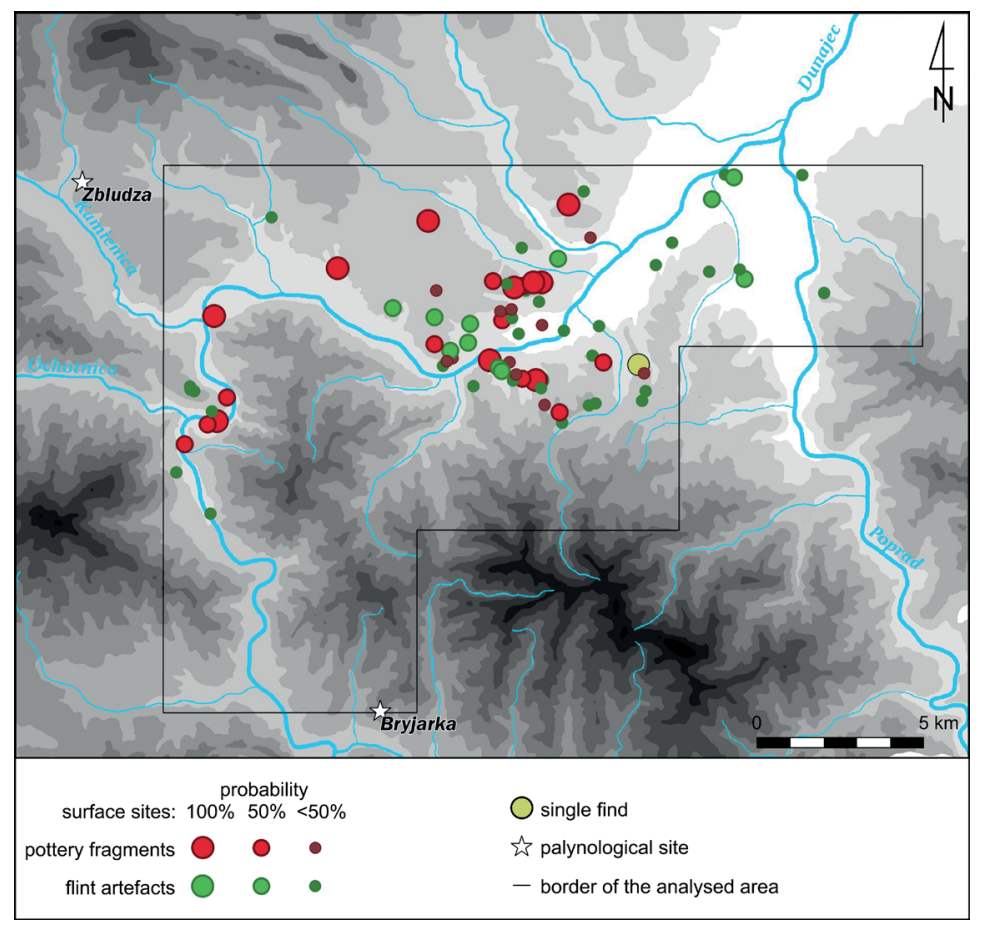

Fig. 2. Middle Dunajec River basin. Location of the Neolithic sites; drawn by the author 
forming an enclave with 2-3 clusters of surface sites. Singular finds of Neolithic pottery sherds were also recorded on the edges of the Łacko Basin. Several sites of uncertain dating are located further up the valley, near the mouth of the Ochotnica River, whereas the Sacz Basin is almost devoid of finds - only a few flint inventories were discovered there, and their assignment to this phase is debatable.

The Eneolithic settlement correlates significantly with the previous pattern, although it seems to be more compact (Fig. 3). The centre of the network moved to the left bank terrace of the Dunajec River near Kadcza and the adjacent hills. As in the Neolithic, the sites with finds of pottery fragments are concentrated in several clusters. The second enclave, much smaller, functioned in the narrower section of the valley by the mouth of the Ochotnica River. Single finds of flint and stone artefacts confirm also at least sporadic human presence on the southern outskirts of the Sacz Basin.

The settlement network was noticeably dispersed in the Early Bronze Age (Fig. 4). For the first time, the evident cultural diversity in the analysed area was also proven. In the eastern part, on the outskirts of the Sacz Basin and in the Poprad River valley, a few surface sites with pottery characteristic of the Pleszów

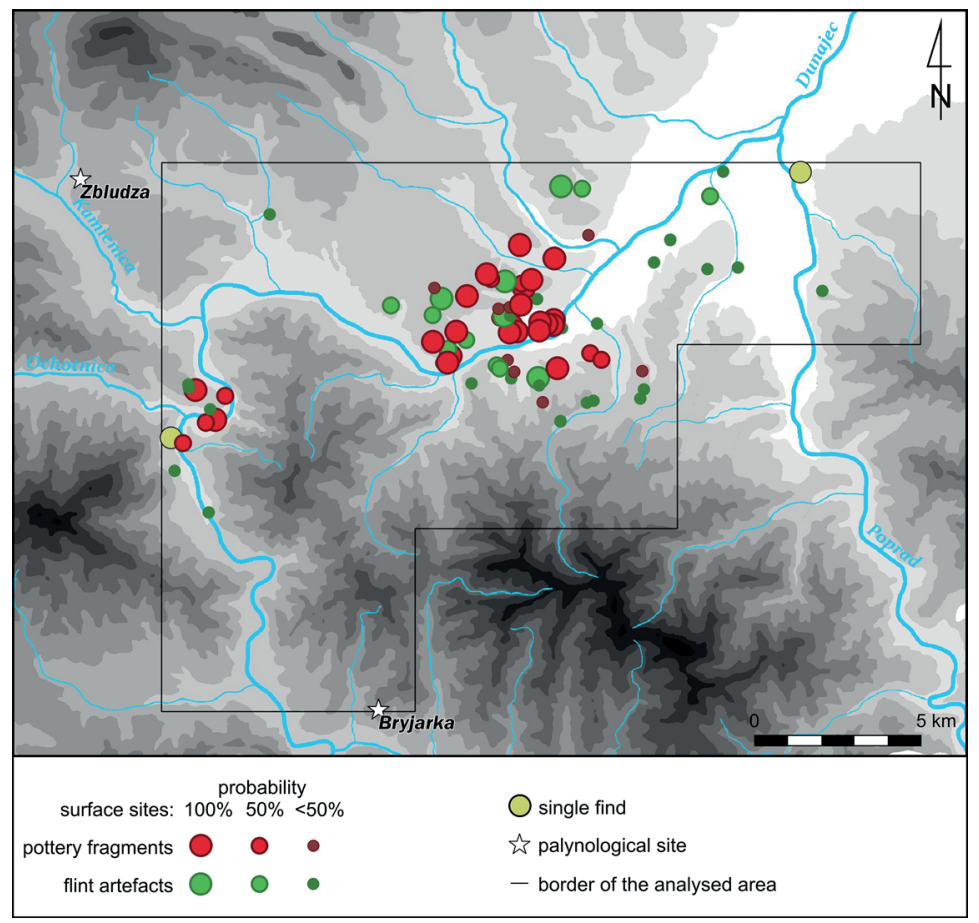

Fig. 3. Middle Dunajec River basin. Location of the Eneolithic sites; drawn by the author 


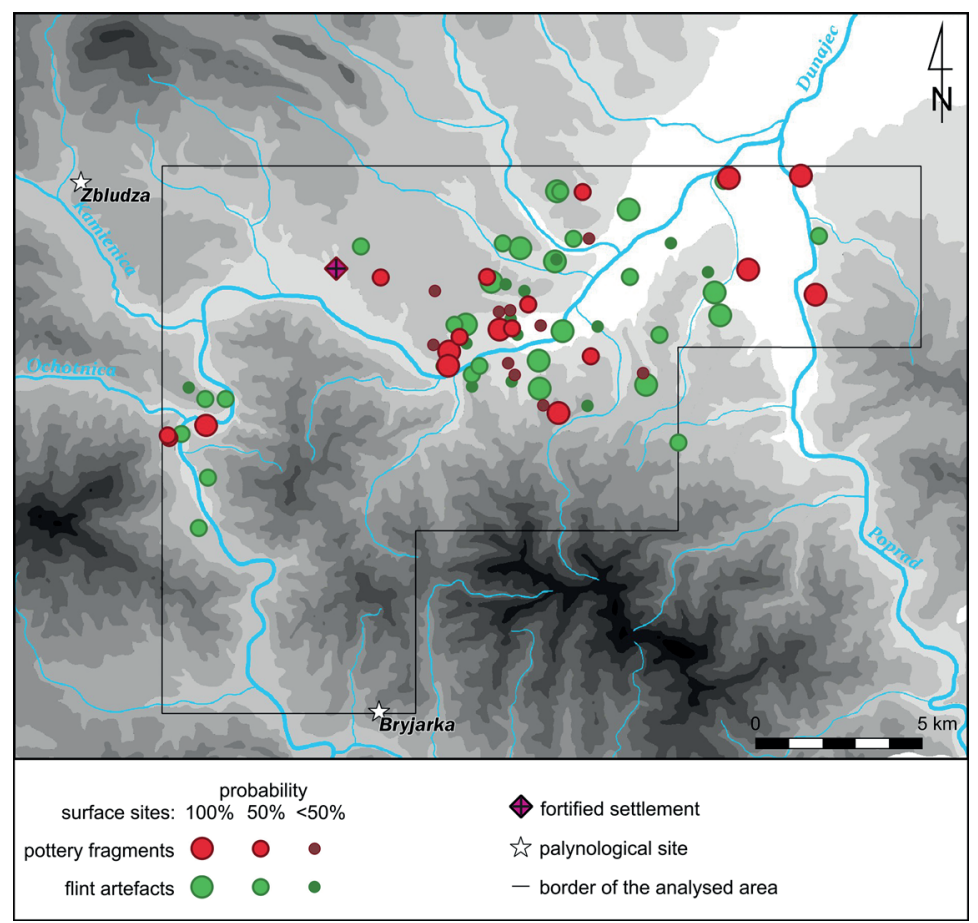

Fig. 4. Middle Dunajec River basin. Location of the sites from the Early and Middle Bronze Age; drawn by the author

group of the Mierzanowce culture were recorded. In the west, the predominant point is the fortified settlement at Maszkowice representing the Transcarpathian Otomani culture (Przybyła, Skoneczna 2014). Between these two zones, near Kadcza, there is a cluster of sites with finds of pottery fragments probably referring to both cultural traditions. To the east of this concentration spreads a zone with flint inventories. Single traces of settlement were also recorded near the mouth of the Ochotnica River. It is not possible to determine mutual relations within the settlement network in the entire analysed area, although it seems that some sites may have been partly contemporary (cf. Przybyła, Markiewicz 2020).

The settlement developed intensely in all analysed zones at the end of the Bronze Age and in the Early Iron Age (Fig. 5). The several-fold increase in the number of sites was accompanied by a significant extension of the ecumene to areas further from the main river valleys. Traces of settlement are rather evenly distributed, and some gaps probably result from the state of research or disadvantageous environmental conditions (Przybyła, Markiewicz 2020). A potential hierarchy of settlement can be demonstrated only by the presence of 


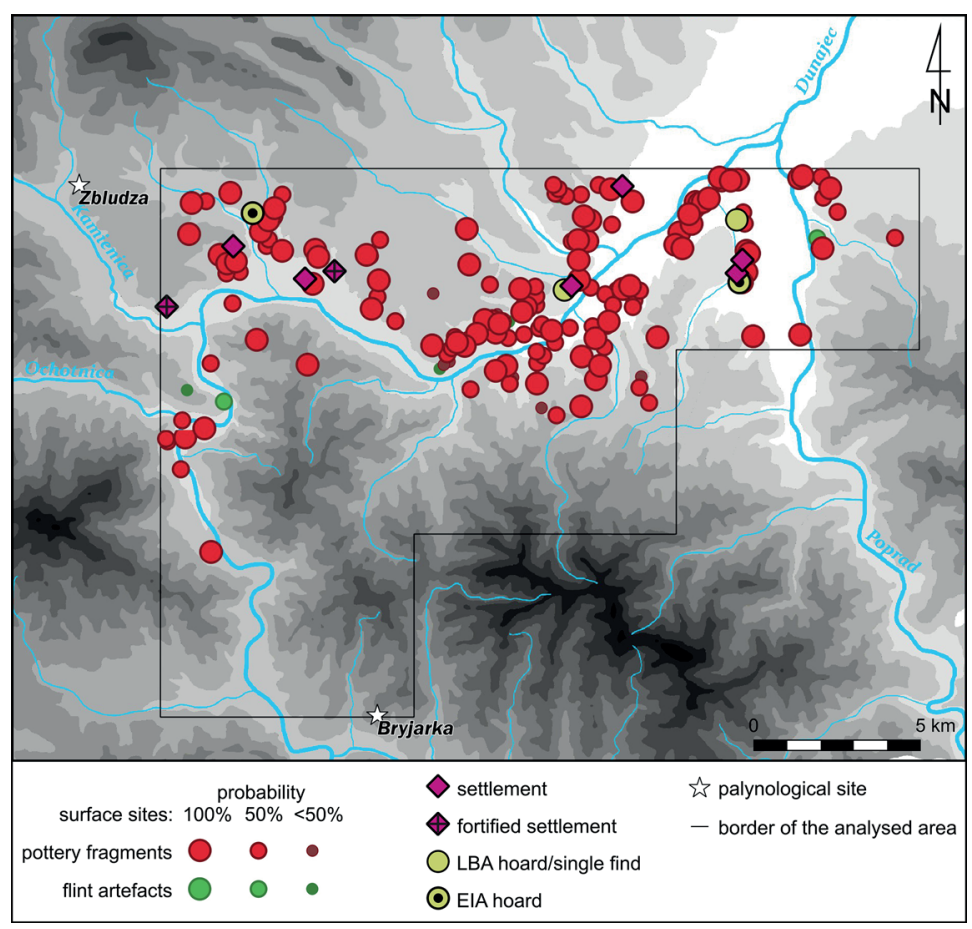

Fig. 5. Middle Dunajec River basin. Location of the sites from the Late Bronze Age and Early Iron Age; drawn by the author

defensive hillforts. The discoveries of hoards and single finds dated to the Late Bronze Age and Early Iron Age are noteworthy (Kostrzewski 1964; Blajer 2001). Bronze artefacts that were discovered at the foot of the Pieniny Mountains, outside the borders of the analysed area, also constitute traces of penetration of the higher sections of valleys (Żurowski 1927; Kołodziejski et al. 1982, 412).

A sharp decline in population density occurred in the late La Tène period (Fig. 6). At that time, the axis of the settlement network was formed by four isolated sites, which are located on small promontories along the Dunajec River valley. The sites at Podegrodzie are accompanied by two settlements lying on a terrace at the foot of the hills.

\section{Settlement preferences}

In the mountains, the main factor limiting the choice of place for a settlement in prehistory had to be the terrain relief. The attractiveness of a given location could be determined by both environmental concerns and economy, as well as strategic 


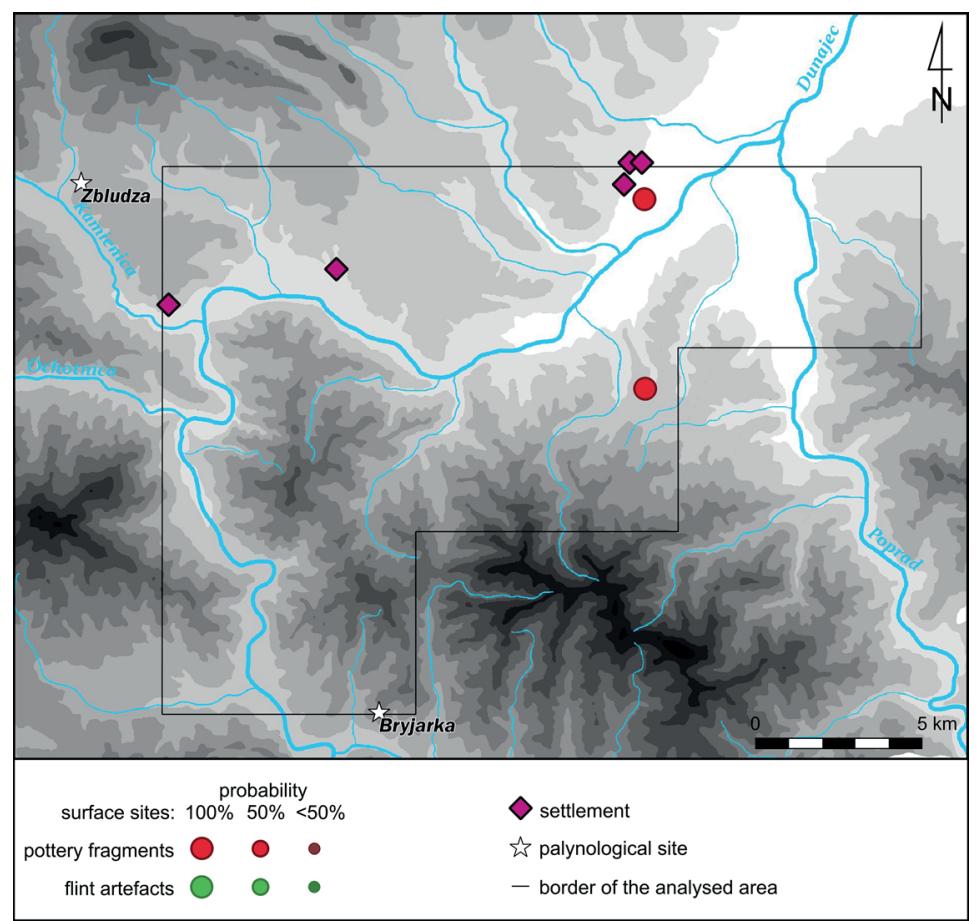

Fig. 6. Middle Dunajec River basin. Location of the sites from the late La Tène Period; drawn by the author

values in terms of communication, observation and defence capabilities. For the analysis, seven types of site location were distinguished, which are characterised by diverse natural conditions (Fig. 7):

- the floodplain (Holocene terrace) of a big valley (the Dunajec/Poprad River);

- a terrace (the lowest Pleistocene terrace) of a big valley (the Dunajecl Poprad River);

- a hillside above a big valley (the Dunajec/Poprad River);

- the culmination of a small hill/promontory above a big valley (the Dunajec/ Poprad River);

- the bottom part of a side valley;

- a hillside above a side valley; and

- the culmination of a ridge separating side valleys.

In the analysed area, traces of Neolithic settlement occur almost exclusively on high terrain forms - on slopes and culminations of hills. A quite explicit tendency is also to colonise mainly the side-valleys zones, away from the main rivers. The Neolithic sites of uncertain chronology are similarly distributed. 

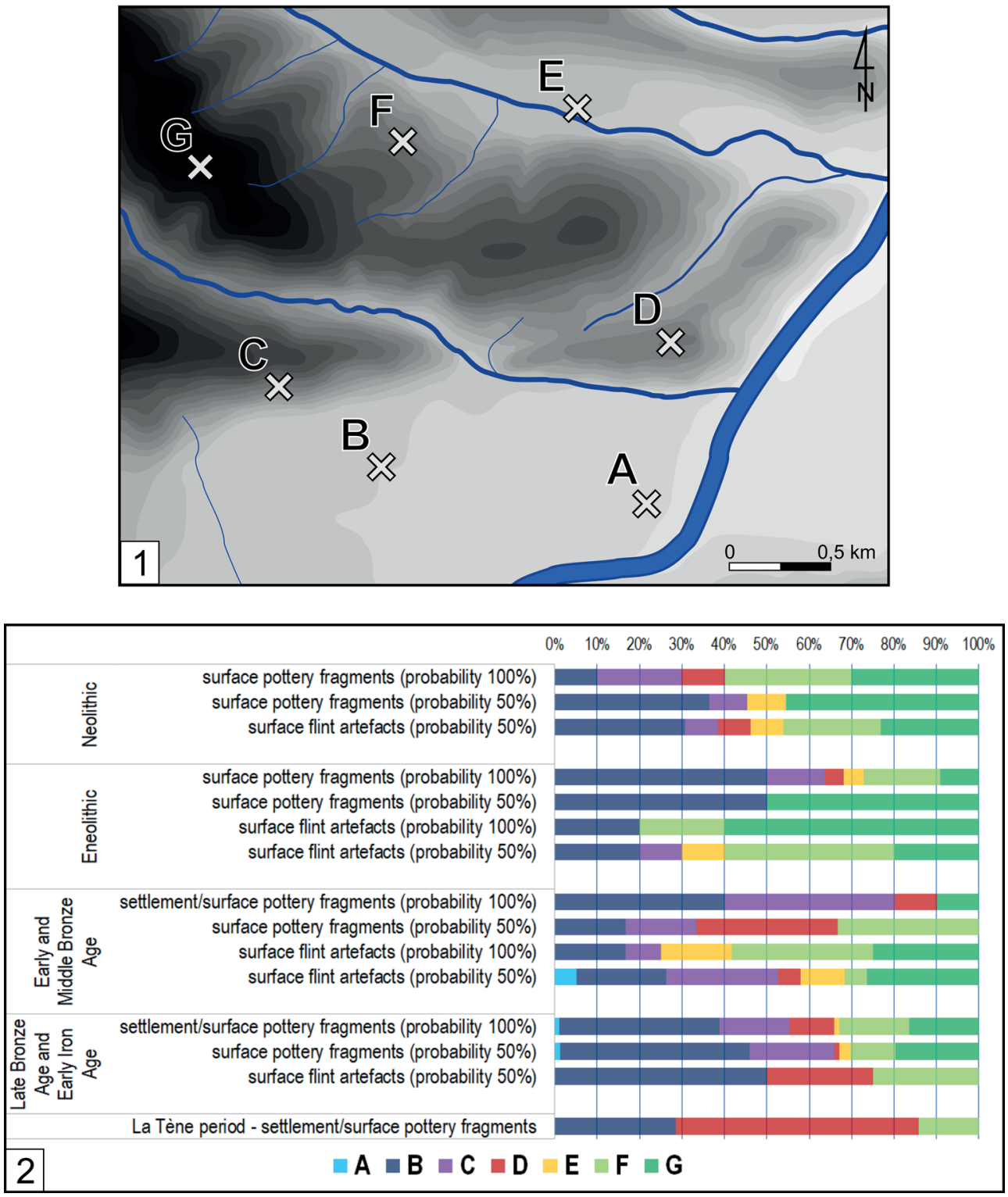

Fig. 7. 1 - Examples of site locations on the distinguished terrain forms; 2 - location of sites on the distinguished terrain forms in the middle Dunajec River basin in each chronological period. A - the floodplain of a big valley; $\mathrm{B}$ - a terrace of a big valley; $\mathrm{C}$ - a hillside above a big valley; $\mathrm{D}$ - the culmination of a small hill/promontory above a big valley; $\mathrm{E}$ - the bottom part of a side valley; $\mathrm{F}$ - a hillside above a side valley; $\mathrm{G}$ - the culmination of a ridge separating side valleys; drawn by the author 
The Eneolithic period shows a change in preferences connected with the aforementioned shift of the settlement network centre to the left bank of the Dunajec River near Kadcza. The surface sites with pottery fragments are situated primarily on the main river terrace and on the adjacent hillsides. It is worth noting that the exact opposite trend occurs in the sites with flint artefacts, which are usually registered in the area of side valleys, on high slopes and ridges.

The older phases of the Bronze Age provide even more evidence for preference of the big-valley zones. At the same time, more often than in the previous period, higher terrain forms were chosen for the settlements, mostly hillsides above wide terraces. There is also a noticeable increase in interest in the low, hardly accessible promontories rising above the main valleys. The surface sites with flint artefacts are, as before, situated mainly in the side-valleys zones, although this tendency is not that clear in the case of the Bronze Age inventories of uncertain chronology.

Settlement preferences at the end of the Bronze Age and in the Early Iron Age are very close statistically to the situation in the Eneolithic - primarily, the wide terraces of major rivers and the adjacent hillsides were inhabited, although, compared to in the second part of the Younger Stone Age, higher terrain forms were more often chosen. In comparison to the Early and Middle Bronze Age, the sites with pottery fragments are more frequent in the side valleys and ridges, a fact associated with the mentioned extension of the ecumene. The intensification of the colonisation process also included the strategically located hills and promontories rising above the terraces of major rivers. Although the percentage of such locations among the registered sites is small, it should be emphasized that traces of settlement of this phase were found on almost all terrain forms of this type within the analysed area.

As mentioned, a series of sites located on small hills rising above the Dunajec River valley form the basis of the late La Tène period settlement network. The highland settlements are accompanied by villages lying on the terrace. A site recorded on the slope of a small side valley deep in the Radziejowa Range seems to be completely isolated.

The universal tendency of the prehistoric settlement in the analysed area is the preference of elevated terrain forms - slopes and culminations of hills. The colonisation of the fertile areas of terraces of major rivers seems to have occurred more frequently during the periods of demographic growth. Not surprisingly, the floodplains and bottoms of side valleys had marginal significance for settlement, as they were exposed to regular flooding. Unlike the sites with pottery, the flint inventories occur primarily in the side-valleys zones, although this contrast was clearly marked for the first time only in the Eneolithic. It is also worth noting that the observed settlement preferences in terms of terrain forms are closely connected with access to agriculturally valuable soils. The location of a settlement 
directly in the Dunajec or Poprad River valley enabled the exploitation of fertile Fluvisols. On the other hand, the sites distant from the main valleys are more often registered in the eastern part of the analysed area, near the Sacz Basin, where the soil conditions were slightly more favourable than on the higher ridges of the Beskid Wyspowy Mountains, Beskid Sadecki Mountains and Gorce Mountains.

\section{Climate, environment and economy}

The Neolithic period in the area in question lasted during the so-called Holocene Climate Optimum and was marked by at least two more humid phases (Margielewski 2006). The palynological studies show that the nearby Poprad Basin area was dominated at the time by vegetation typical of wetlands (Hajnalová 1996). It seems possible that similar environmental conditions prevailed in the Sacz Basin and its surroundings. The unfavourable conditions for agriculture which prevailed at the bottom of basins and wide valleys correspond well with the observed tendency to inhabit higher parts of the landscape, distant from the major rivers. It is worth noting that a similar phenomenon was recognized in the settlement patterns of the Linear Pottery Culture on both sides of the Western Carpathians: in the Wiśnicz Foothills and Spiš (Soják 2000; Valde-Nowak 2009). Therefore, the first settlers in the middle Dunajec River basin were probably attracted by the presence of favourable environmental niches, although it cannot be excluded that the proximity of the Pieniny radiolarite outcrops played a role as well (cf. Rydlewski 1989; 2009). So far, however, the only evidence of agricultural activity in the region is provided by the cereals and synanthropic plant pollen recorded in the discussed palynological core from Zbludza.

The development of the Eneolithic cultures in the area should probably be correlated with the beginnings of the Subboreal period, which was marked by humid climate fluctuation. As already mentioned, in the palynological profiles from the neighbouring regions there are noticeable changes at the Subboreal level that may indicate human activity and forest fires. There is no evidence to conclude that this phenomenon was associated with the development of pastoral economy and creating woodless areas for pastures. However, it should be pointed out that the described settlement pattern with surface flint inventories sites in the side-valleys zones fits well with the economic model based on summer highland pasturing ( $c f$. Valde-Nowak 1995). On the other hand, the fact that the centre of the settlement network was moved to the Dunajec River terrace should be considered in the context of the climate fluctuations mentioned above. If the humid episode registered in the Beskid Makowski Mountains and Beskid Wyspowy Mountains in the first half of $4^{\text {th }}$ millennium BC had a significant impact on the environmental conditions in the analysed area and slowed down 
the drainage of river terraces, it is probable that the development of the Eneolithic settlements in the lowest zones of the Dunajec River valley took place only after this period.

During the Early and Middle Bronze Age, another horizon of anthropogenic changes in the local vegetation was marked in the Zbludza profile. Although no archaeological sites from this period have been recorded in the immediate vicinity of the peat bog, human activity in the region is well confirmed by the finds from the Łacko Basin. The analysis of plant macro-remains and animal bones from the Early Bronze Age hillfort at Maszkowice provides insight into the economic strategies of the local populations (Przybyła, Gocman, Mueller-Bieniek 2020). The predominance of wheat - a species which requires specific environmental conditions - among the cultivated cereals indicates that the Dunajec River terrace was under intensive agricultural exploitation. The analysis of animal remains does not provide reliable evidence for the practice of transhumance, but, undoubtedly, at least part of the cattle, sheep and goat grazing took place at some distance from the settlements. As in the previous period, the traces of such activities can be found at the aforementioned surface sites with flint artefacts, which are situated in the side valleys zone.

In the last phase of the Bronze Age, contemporary to the end of the Subboreal period, a diversification of economic strategies was observed in the discussed region, which was probably related to more extensive strategies of environmental exploitation leading to development of settlements in the previously uninhabited areas (cf. e.g. Kienlin, Korczyńska, Cappenberg 2014; Moskal-del Hoyo et al. 2015). As mentioned, the deforestation contemporaneous with the increase in population density in the Early Iron Age is perceptible both in the pollen profiles and in the species composition of plant macro-remains from the settlement at Maszkowice. The noticed settlement expansion towards the hills and side valleys was probably the result of dense inhabitation of the Dunajec River terraces and adaptation of agriculture and animal husbandry strategies to less favourable environmental conditions. The settlements lying on the borders of both zones, on the culminations of promontories rising above the bottom of the main valley may have enjoyed a privileged position in such an economic system (cf. Tunia 1989; Przybyła, Skoneczna, Vitoš 2012; Kienlin, Korczyńska, Cappenberg 2014). One such settlement was the hillfort at Maszkowice. The paleozoological data from excavations indicate that the local population practised specialized cattle husbandry, and the animals could have been grazed both on the Dunajec River terrace and the neighbouring hills. At the same time, the growing importance of barley and millet among the cultivated cereals indicates more intensive agricultural exploitation of Dystric Cambisols. This phenomenon may have resulted from limited access to the densely populated Dunajec River terrace, or from a need to move crops to higher areas due to the adverse climate change 
at the beginning of the Subatlantic period (Przybyła, Gocman, Mueller-Bieniek 2020; cf. e.g. Margielewski 2006; Groenman-van Waateringe, van Geel 2017).

The palynological data do not demonstrate any significant decrease in human activity during the late La Tène period, although, as mentioned, the archaeological record shows a major settlement crisis. The location of most of the known sites on the hills adjacent to the Dunajec River valley is suggestive - such terrain forms offered, apart from the defensive advantages, favourable conditions for various economic strategies (Madyda-Legutko, Tunia 2015, 355). Importantly, these settlements were situated in the places that were inhabited in the previous period, therefore in the environmental zones that were already heavily transformed by human activity and adapted to agriculture and animal husbandry. The lack of paleobotanical and paleozoological data from the excavated sites does not allow reconstruction of the economic system of that time. So far, the only potential direct testimony of agricultural activity may be provided by the alleged iron deposit from Zabrzez, which consists of the metal elements of a harrow (Jędrysik et al. in print).

\section{DISCUSSION}

The settlement dynamics in the middle Dunajec River basin in the cultural context

According to the current state of research, a stable Neolithic settlement did not develop in the mountain zone of the Polish Western Carpathians; the southernmost enclaves were recognized in the foothills (cf. e.g. Valde-Nowak 1988; Kamieńska, Kozłowski 1990; Kaczanowska 2006; Czekaj-Zastawny 2008). Therefore, the discovery of surface sites with pottery fragments of Neolithic provenance is somewhat surprising in the area south of the Sacz Basin. Unfortunately, due to the lack of verification of these sites through archaeological excavations, it is currently impossible to formulate a more solid interpretation of the nature of the registered traces of settlement. However, it should be once more emphasized that in terms of environmental conditions this enclave does not differ significantly from those in the nearby Wiśnicz Foothills or the upper Poprad and Hornad River basins - in each case, the high slopes and culminations of gentle hills and ridges were inhabited, which are covered with relatively fertile soils and rise to a height of about $40-50 \mathrm{~m}$ above the bottom of the stream valleys. Importantly, the settlement microregion in question lies by the trail of the postulated Neolithic communication route, passing through the Western Carpathians along the Dunajec and Poprad River valleys (Soják 2000, 201-202; Valde-Nowak 2009, 27-28). 
Interpretation of the character of the Eneolithic surface sites in the considered territory in the regional context presents some difficulties due to the lack of cultural identification of the pottery findings. It seems, however, that the overall settlement dynamic in the middle Dunajec River basin corresponds to the general trends characteristic of the area of western Lesser Poland - the settlements were located within the same enclaves as in the previous period, although there was some variation in economic strategies resulting in the expansion of ecumenes ( $c f$. Kruk 1980, 329; 1981).

As mentioned, the analysed area became a border - or a contact zone - of two cultural traditions in the Early Bronze Age. Sites of the Mierzanowice culture discovered during surface surveys on the southern outskirts of the Sacz Basin are the southernmost traces of the Pleszów group's settlement (Kadrow, Machnik $1997,122)$. In the western part of the area in question, an isolated settlement at Maszkowice in the Łacko Basin - a hillfort representing the Transcarpathian cultural tradition - is a unique phenomenon in this period. Apart from the pottery characteristic of the Otomani culture, attention is drawn to the fragments of three ${ }^{4}$ figurines made of local clay, whose forms find analogies in the grave inventories in the northern Balkans and Mycenaean culture. The nature and construction of the stone fortifications surrounding the Early Bronze Age village indicate that its inhabitants were familiar with the architecture typical of southern Europe in this period. It seems, therefore, that this hillfort was built by a group of newcomers from the southern side of the Carpathian arch, wishing to join the long-distance exchange network by establishing a representative defensive settlement on one of the main communication routes (Przybyła, Skoneczna 2011; 2014; Przybyła 2016). The current state of research does not allow determination of whether the representatives of the Mierzanowice culture who left traces of their presence in the southern outskirts of the Sacz Basin participated in this exchange system. However, the significant dispersion of sites from this period and their location directly above the Dunajec and Poprad River valleys may suggest a dominant role of long-distance communication in the shaping of the cultural reality in the analysed area in the Early Bronze Age.

A detailed analysis of artefacts from the excavated sites revealed the existence of a centuries-long cultural hiatus in the area, covering the end of the Middle and part of the Late Bronze Age; one can claim some settlement crisis at that time in the entire middle Dunajec River valley (Korczyńska, Przybyła 2020; Przybyła, Markiewicz 2020). The settlement "boom" at the end of the Late Bronze Age and in the Early Iron Age corresponds to the demographic growth and reorganization of settlement occurring at that time in the whole of western Lesser Poland (cf. Gedl 1982; Rydzewski 1986). In terms of cultural

${ }^{4}$ Kind information from Prof. Marcin S. Przybyła. 
character, the middle Dunajec River basin was a zone of permeation of the elements typical of the Transcarpathian regions and of western Lesser Poland, where the settlement of the Upper Silesian-Lesser Poland group of the Lusatian culture dominated (Cabalska 1974; Gedl 2003; Przybyła 2009, 243-246). The apparent concentration of sites in the immediate vicinity of Dunajec River was also registered in the lower course of this river in the Wiśnicz Foothills. This phenomenon is interpreted as a manifestation of the growing importance of communication factors in settlement development (Kienlin et al. 2011). The important role of this axis of Transcarpathian contacts may also be indicated by the shift of the borders of the ecumene further to the south. The presence of long-inhabited defensive settlements providing an excellent view of vast areas of the main valley is also essential. It seems that they could have acted as central places of a kind, although their possible political and economic control and the existence of hierarchical structures is under discussion (cf. e.g. Przybyła, Skoneczna, Vitoš 2012; Kienlin, Korczyńska, Cappenberg 2014).

Another crisis in the area in question is correlated with the end of the functioning of the so-called Zabrzeż-Podegrodzie horizon settlements at the beginnings of the La Tène period (Madyda-Legutko 1995). At present, it is not possible to determine the duration of the presumed hiatus or to characterize the relationships between the local population and the representatives of the Celtic cultural tradition who appeared in the Sacz Basin in the La Tène C2 phase (around the turn of the $3^{\text {rd }} 2^{\text {nd }}$ century BC; Woźniak 2004, 49; Madyda-Legutko, Tunia 2015). The late La Tène settlement pattern with highland defensive settlements and open villages located below is characteristic of the core territory of the Púchov culture in the Vah River basin (Pieta 1982). It is noteworthy that the Púchov sites in the analysed area are located in the same places as the Zabrzeż-Podegrodzie horizon settlements. However, stratigraphic analyses of the excavated sites did not provide premises for postulating a continuity of settlement (Madyda-Legutko 1995, 259-260; Przybyła, Skoneczna, Vitoš 2012; Jędrysik et al. in print).

Throughout the analysed chronological range, the discussed part of the middle Dunajec River basin was included in the cultural phenomena typical of the areas north of the Carpathians, but for the most time it remained under the influence of southern impulses. In the model of S. Czopek, the territory in question was situated within the boundaries of the Western Carpathian "A" zone, which was characterized by strong cultural links with the Spiš and Orava regions (Czopek 2005). The location at the intersection of different stylistic currents favoured the shaping of the cultural model in the discussed zone with specific, individual features. In some sections of the younger prehistory, even the existence of some kind of settlement and cultural continuity in the Dunajec River valley can be claimed (Przybyła 2009, 248). 


\section{Prehistoric settlement in the Western Carpathians and Alps - case studies}

In order to better understand the impact of various environmental and cultural factors on the settlement development in the middle Dunajec River valley, three other sample areas from the Western Carpathians and Alps have been similarly analysed. The results of these studies are discussed in detail in a separate paper (Markiewicz 2020). Below, only basic information on each case study will be presented, as well as comparative observations regarding settlement dynamics in subsequent chronological phases.

Of the geographical areas being analysed, that closest to the Dunajec River valley covers the western part of the Slovakian Spiš encompassing the upper Poprad River basin. Within this geographically diverse area, several mountain ranges surround the Poprad Basin. A relatively small number of the recorded sites were subject to systematic excavations - almost three-quarters of the approximately 140 traces of settlement from the discussed period are surface finds of pottery fragments, whose chronological assignment is often imprecise or uncertain. Similarly, flint inventories of indeterminate dating constitute a significant percentage (cf. e.g. Javorský 1983; Soják 1999; 2015).

Montafon is a relatively narrow valley lying in the Central Alps in western Austria and extending over a length of about $40 \mathrm{~km}$ from its mouth to the Bielerhöhe Pass. A part of the Walgau valley being a continuation of the Montafon as well as side valleys were included in the analysis. The number of archaeological sites from the period in question is very small - among the slightly more than 20 registered points, 5 are multicultural settlements; a high percentage are also single finds of bronze artefacts (Krause 2007; Reitmeier 2012; Bringemeier et al. 2015).

The Mesolcina valley, approx. $40 \mathrm{~km}$ long, lies in the Lepontine Alps in southeastern Switzerland and extends from the San Bernardino Pass in the north, joining the Ticino River valley in the south, a small fragment of which has been included into the analysed area. Due to significant differences in the height of the valley bottom, this region is characterized by varied environmental conditions. Most of the currently known prehistoric sites have been excavated. About a dozen of the over 40 archaeological sites included in the analysis are multiphase or multicultural; most of them are cemeteries dating to the younger parts of prehistory (Della Casa 2000; Carlevaro 2013).

In the Montafon valley, there are no traces of the Neolithic cultures developing in the north and west of the Alps, which were characterized by lake dwellings - this area did not offer the preferred environmental conditions to the population of these groups ( $c f$. e.g. Jacomet 2006). The Younger Stone Age is poorly represented in the Mesolcina as well - the settlements near its mouth 
functioned in some isolation from the northern Italian cultural centres, and the archaeological traces and paleoenvironmental data from the deeper parts of the valley demonstrate only sporadic or seasonal exploitation of these areas, probably by pastoral communities. The character of the registered sites in terms of culture and environment seems to refer, on the one hand, to the model functioning several kilometres south, in the region of Lake Varese, while on the other to the settlement forms typical at that time of the Alpine valleys ( $c f$. Della Casa 2000). The settlement situation in Spiš is better recognized. Like the analysed area of the middle Dunajec River basin, the beginnings of the permanent settlement are associated with the influx of people representing the Neolithic Linear Pottery cultural model. The concentration of sites in small micro-regions and the specific husbandry and agriculture strategies reflect well the nature of the "Danubian" economic system (Soják 2000). A specific feature of the reconstructed settlement pattern, likewise in the Dunajec River basin, is the previously mentioned tendency to colonise higher parts of the landscape, which probably resulted from the adverse environmental conditions prevailing in the Poprad Basin (Hajnalová 1996, 282). The absence of younger "Danubian" cultures and a vague early Eneolithic horizon are problematic. These phenomena are usually explained by worsening climate conditions (Soják 2003, 125). Settlements flourished again in the late Eneolithic, when this zone was dominated by the Baden cultural model (cf. Horváth, Svingor 2015).

In the Bronze Age, the role of Spiš in supra-regional cultural transmission was more evident than in the previous periods, which is indicated, among others, by mixed stylistic influences manifesting in the pottery forms and ornaments (Przybyła 2009, 151-156). In terms of settlement patterns, the region shows some specific features - no settlement structures typical of the neighbouring tell cultures and Epi-Corded Ware tradition have been recognized. On the other hand, similarly to the Polish part of the Western Carpathians, there are sites with flint inventories of the so-called Orava type, which are associated with specific economic strategies (Valde-Nowak 1988, 97; Soják 2003, 133). Meanwhile, the Early Bronze Age period coincides with the beginnings of inhabitation of the Montafon valley. Like the hillfort at Maszkowice, a settlement was established "on the raw root" at the Friaga Wald site at Bartholomäberg; the paleoenvironmental data indicate violent and invasive human impact in the local vegetation through fires and deforestation (Röpke, Krause 2013). The significance of the region undoubtedly increased during the Middle Bronze Age, when one of the oldest stone fortifications in the Alps was built around the settlement and at the same time a strategic observation point on Diebschlössle Hill at the entrance to the valley was adapted. The reasons for this rapid colonisation are not quite clear, although it seems that the decisive factor attracting settlers to these areas may have been the presence of copper ore deposits. There are indications that the area 
in question played an important role in the regional economic system, which was connected if not with copper ore mining, then perhaps with the communication route leading through the mid-mountain passes to the Eastern Alps. Such relations are visible in the styles of pottery from the excavated sites (Krause 2007).

In the Mesolcina valley, there is only one archaeological site from the Early and Middle Bronze Age. A significant settlement development took place only in the youngest part of this period and was supposedly associated with the arrival of the new population from the northern side of the Alps representing the Canegrate culture (Blake 2014, 28). An important microregion was formed then in the upper part of the valley in the Mesocco area, where a major settlement with an "observation station" functioned. It is believed that this phenomenon was related to the acquisition of control over one of the main transalpine routes leading through the San Bernardino pass to the Upper Rhine valley (Della Casa 2007). At the same time, the inhabitation of the Montafon valley declined - from its immediate vicinity, only single finds of bronze artefacts are known. In the upper Poprad River basin, the settlement structures stabilized, which corresponded well with the cultural model of the Urnfield tradition dominating in Central Europe. The increase in population density is demonstrated in the palynological record as well (Hajnalová 1996). As in the previous period, the intertwining of various stylistic trends was manifested in the material culture (Miroššayova 1992; Przybyła 2009, 154-155).

The younger part of the Early Iron Age and the beginnings of the La Tène period mark the next stage in the settlement development in the Central European mountains. As mentioned, settlements of the Zabrzeż-Podegrodzie horizon functioned at that time in the Dunajec River basin. A similar phenomenon was recorded in the Slovakian Spiš: a decrease in demographic potential was accompanied by the tendency to build settlements on high, naturally defensive terrain forms (Miroššayova 1992). These observations correlate with the cultural changes that occurred in the neighbouring regions and are usually explained by political unrest or adverse climate fluctuations (cf. e.g. Miroššayova 1987; Chochorowski 1993; Madyda-Legutko 1995). In the palynological record of the western and eastern parts of the Poprad Basin, intensive deforestation is observed at the beginning of the Subatlantic period (Hajnalová 1996, 281). At the same time, the intensity of colonisation of the Montafon region increased again. Despite the prevalence of the cool and humid climate episode, there was a renewed expansion of agriculture and animal husbandry manifesting in palynological profiles. This process was probably facilitated by the irreversible anthropogenic changes in the vegetation that occurred in the Bronze Age. Simultaneously, the exploitation of local iron ores deposits began (Bringemeier et al. 2015; Krause, Würfel 2015).

Despite the unfavourable climatic changes in the last centuries BC, in the Mesolcina valley the population density increased. In the palynological record 
from various parts of this area, the intensification of anthropopressure is visible, which accompanied the reorganization of the settlement network at the beginning of the Iron Age. The presence of numerous imports in the grave inventories at the cemeteries from this period proves that the local population still participated in long-distance exchange (Della Casa 2000; Carlevaro 2013, 43-45). The cultural development was not shaken by the regional transformations and the Celtic expansion at the beginning of the Second Iron Age. The decentralization of settlement network analogous to that in the foothills shows that the area in question was fully included in the range of socio-political processes occurring in northern Italy ( $c f$. Carlevaro 2013, 121-126). In the younger phases of the La Tène period, the upper Poprad River basin was also within reach of the main cultural phenomena - similarly to in the middle Dunajec River basin, the settlement structures of the Púchov culture developed here (Soják 2003, 140-143).

\section{Models of the prehistoric settlement development}

in the Central European mountains

The settlement dynamics in the discussed case studies seem to be very diverse and largely dependent on the local environmental and cultural conditions. In the light of the collected data, however, it is possible to indicate some general regularities in the cultural and settlement development in the Central European mountains.

In terms of environmental conditions in the middle Dunajec River basin, there is a tendency to concentrate the settlement in specific ecological niches - in small basins and on the sections where the valley of a major river slightly widens and its lower parts are composed of wide terraces and mild, south-facing slopes. The earlier emphasized presence of the settlements on "edge" terrain forms culminations of small promontories by the main valleys - is also characteristic. Similar tendencies are noticeable in the discussed Alpine case studies. Apart from the mentioned Mesocco micro-region, traces of stable settlements were registered in the Mesolcina primarily at the mouth of the valley, on the gentle hillsides and wide river terraces (Della Casa 2000, Abb. 1.1). In the Montafon valley, which is devoid of broad river terraces, the permanent settlement was clustered on a mild, south-faced slope, covered with fertile soils (Krause 2007). In Spiš, the sites located on the hills adjacent to the Poprad Basin are dominant in the prehistoric landscape (cf. e.g. Miroššayova 1992; Horváth, Svingor 2015).

In alpine archaeology, the priority of pastoralism over agriculture in the process of mountain colonisation forms a kind of paradigm (Primas 1999). In the cases discussed above, this thesis is not clearly reflected; there is no doubt, however, that grazing at some distance from the settlements was an important element of the economic system. The presence of shepherds' camps away from 
the contemporaneous villages is confirmed in the region of the Montafon valley; some manifestations of more mobile economic strategies can be seen also in some periods in the Mesolcina valley (Della Casa 2000; Reitmeier 2012; Bringemeier et al. 2015). The situation in the Western Carpathians is less evident. The main problem is the lack of precise dating of most surface sites with flint inventories, which may be traces of various forms of economic activity. However, on the basis of the above-mentioned premises (the specific location of these sites and the results of paleozoological analyses), one can cautiously conclude that in the middle Dunajec River basin some mobile forms of animal husbandry were also practised. Such an interpretation was postulated before regarding other parts of the Polish Western Carpathians and it was based both on archaeological and palaeoenvironmental data (e.g. Valde-Nowak 1988; 1999; Pelisiak 2013).

It is worth noting that a special type of animal husbandry in the form of seasonal pastoralism may have had cultural significance. It seems that in some cases, shepherds were involved in establishing contacts between populations living in different parts of mountain ranges and participated in transmission of ideas and material goods (Przybyła 2009, 41).

In the popular belief, the importance of animal husbandry in the mountains resulted from the fact that this branch of economy, unlike agriculture, was less dependent on climate fluctuations, which had a drastic impact on the environment of the so-called marginal zones (Tinner et al. 2005). It should be noted, however, that the analysis of the above-described cases did not show a clear correlation between the episodes of adverse climate conditions and the overall dynamics of settlement development. As mentioned, the periods of lower demographic potential in Spiš are sometimes explained by climate phenomena. On the other hand, contrary to the intuitive predictions, during the moistening and (possibly) cooling of the climate, which was observed in various parts of Central Europe in the Early and Middle Bronze Age (around 1700-1300 BC; Haas et al. 1998; Margielewski 2006), settlement intensification occurred in the Montafon valley and the middle Dunajec River valley, among other places. Some regularities can be seen on the micro-regional scale in terms of settlement preferences for instance, in the previously discussed phenomenon of moving settlements to lower or higher terrain forms. A very interesting illustration of these processes is the situation in the Mesolcina valley, where the centre of the local settlement network shifted up the valley during the drier and warmer periods, and closer to its mouth during the episodes of humid climate (Markiewicz 2020, 107-108).

In the model approach, the expansion of an ecumene of a given population proceeds through transferring of a familiar organizational pattern of specific size and internal structure of the settlement and the exploited territory to the neighbouring areas. The schema is replicated until there are no more reachable areas with environmental conditions similar to the starting region. The next step 
is the reorganization of the settlement network allowing for more efficient use of available resources (Sherratt 1972, 500). According to this model, as observed in the discussed cases, the development of prehistoric mountain settlement in the wider sections of valleys and areas with a milder terrain relief could proceed freely within the limits of certain economic comfort. At the same time, it seems that going beyond this zone must have been determined by some additional factors.

At the beginnings of the research on the prehistoric settlement in the Western Carpathians, opinions prevailed about the decisive importance of external negative causes ("push" factors; $c f$. Anthony 1990) in the colonisation process of the mountain zone. The areas with naturally defensive terrain forms were to be the obvious direction of escape in the face of political unrest and military threat, or to be the last piece of land occupied under demographic pressure (e.g. Żurowski 1927, 92-93; Čaplovič 1962). Although this interpretation may find historical justification in some cases (e.g. Chochorowski 1993), it should be emphasized that no evidence was found in any of the analysed regions that defensive or demographic reasons were behind the primary motivation for the colonisation of the mountain valleys. The first settlements are not correlated with traces of military aggression, the construction of fortifications is a later phenomenon, and the periods of development and crisis of inhabitation of the described valleys and their forelands often followed each other in different rhythms.

The recent discussions more often emphasize the role of positive factors ("pull") in the early colonisation of mountain zones. The aforementioned mobile husbandry strategies may have played an important role in this process through facilitating - or even forcing - the gradual extension of the ecumene deeper into the mountain valleys ( $c f$. e.g. Geddes 1983; Valde-Nowak 1999). Intuitively, it seems obvious that settlers could have also been attracted by the mountain outcrops of raw materials. However, it should be noted that the exploitation of these deposits did not necessarily result in the establishment of permanent settlements in their vicinity. Such movement may have been connected with better control and operational efficiency, but also with relative worsening of conditions for agriculture; a balance of these two factors determined the decision to migrate. Case studies from various European mountains indicate that permanent settlements were not founded in the analysed chronological range in the immediate vicinity of the outcrops of the desired stone raw materials unless there were favourable environmental conditions for crop farming ( $c f$. e.g. Lech 1987; Petrequin et al. 2007). Traces of stable inhabitancy were not recorded near the Pieniny radiolarite deposits, which were undoubtedly exploited by the prehistoric people living in the middle Dunajec River basin - this fact is confirmed by the findings of radiolarite artefacts from the Younger Stone Age and the Bronze Age (Rydlewski 1989; 2009). The situation should be assessed differently in the case of non-ferrous 
metal ores, which were both rare and particularly desirable in prehistory. Moving settlements to the vicinity of such outcrops resulted not only in better control and economic benefit of the local population but also in the reduction of logistical problems related to the time-consuming process of extraction and pretreatment of raw material. The opportunity to join an interregional exchange network was critical in this undertaking ( $c f$. Pearce, de Guio 1999; Shennan 1999). Such a settlement development model corresponds to the situation in the Early and Middle Bronze Age in the Montafon valley (Krause 2007).

Similar settlement phenomena can be expected in the case of the aforementioned desire of a given community to join in a long-distance trade network. The decisive role of this factor is evident in the middle Dunajec River and Mesolcina valleys in the Bronze Age. The microregion at Mesocco in the Swiss Alps is a typical example of taking control of a "bottleneck" on a main communication route, which enabled economic benefits from restricting access to the transported goods (Della Casa 2007; cf. Earle et al. 2015). The cultural character of the above-discussed Early Bronze Age hillfort at Maszkowice leaves no doubt as to its role in the long-distance contacts. A secondary phenomenon, although one conditioned by the same mechanism of the increasing importance of the transport route, was probably the tendency visible in later periods to cluster settlements directly along the main river valleys, often at points of particular observational advantage.

Finally, in the context of exchange networks, the cultural role of mountain areas should be mentioned. At present, the statement that prehistoric mountain ranges were not significant communication barriers is rather a truism. These zones crossed by long-distance routes served as intercultural links, being at the same time active participants in the networks of mutual dependencies and exchange. The intertwining of various stylistic trends combined with specific patterns of settlement and economy sometimes led to formation of a distinctive cultural model on their territories.

\section{CONCLUSION}

In the process of prehistoric colonisation of the middle Dunajec River basin, three main stages can be distinguished, which are largely universal for other European mountains, despite some differences resulting from the local natural and cultural conditions.

The first stage falls in the Younger Stone Age and is associated with the penetration of these areas by the first farmers and herders in search of the environmental niches that offered favourable conditions for the not yet flexible economic strategies. The Neolithic sites are located in the zones similar to the 
nearest settlement enclaves in terms of natural conditions. During the Eneolithic period, despite the economic development and extension of the ecumene, the process of colonisation of mountain landscapes was still determined primarily by environmental factors.

The next stage is marked by the widespread cultural transformations at the beginning of the Bronze Age, which were connected with the growing importance of the long-distance exchange networks and metallurgical production. The most common motivation to settle in the mountain valleys during this period was to benefit from the control of local resources or communication routes, which compensated for the discomfort resulting from isolation and less favourable environmental conditions. Characteristic elements in the cultural landscape were the individual settlements in the naturally defensive places that offered both observational advantages and access to areas relatively favourable for agriculture and animal husbandry.

The final stage is correlated with the end of the Bronze Age and the Early Iron Age. It seems that it was during this period that the mountain environmental barrier was finally overcome and the rhythm of local settlement changes synchronized with cultural phenomena of supra-regional range. The colonisation intensified not only in the areas of a special strategic role and the most favourable conditions for farming and husbandry, but also in the areas that had been previously penetrated only seasonally or sporadically. Therefore, the settlement development in the subsequent periods was less limited by environmental or communication factors and progressed in a fully "familiarised" landscape.

\section{REFERENCES}

Anthony D. W.

1990 Migration In Archaeology: The Baby and the Bathwater, American Anthropologist 92:4, p. 895-914.

Blajer W.

2001 Skarby przedmiotów metalowych z epoki brqzu i wczesnej epoki żelaza na ziemiach polskich, Kraków.

Blake E.

2014 Social networks and regional identity in Bronze Age Italy, Cambridge.

Bringemeier L., Krause R., Stobbe A., Röpke A.

2015 Expansions of Bronze Age Pasture Farming and Environmental Changes in the Northern Alps (Montafon, Austria and Prättigau, Switzerland) - An Integrated Palaeoenvironmental and Archaeological Approach, [in:] The third food revolution? Setting the Bronze Age table: common trends in economic and subsistence strategies in Bronze Age Europe, J. Kneisel, M. Dal Corso, W. Kirleis, H. Scholz, N. Taylor, V. Tiedtke (eds.), Universitätsforschungen zur prähistorischen Archäologie, vol. 283, Bonn, p. 181-200. 
Bucała A., Margielewski W., Starkel L., Buczek K., Zernitskaya V.

2014 The Reflection of Human Activity in the Sediments of Iwankowskie Lake from

Subatlantic Phase (Polish Outer Carpathians), Geochronometria 41:4, p. 377-391.

Cabalska M.

1963 Osadnictwo kultury tużyckiej w rejonie średniego biegu Dunajca w świetle badań w Maszkowicach pow. Nowy Sacz, Zeszyty Naukowe Uniwersytetu Jagiellońskiego,

Cabalska M. vol. 73, Prace Archeologiczne, vol. 5, Kraków, p. 41-57.

1965 Sprawozdanie $z$ prac wykopaliskowych przeprowadzonych na stanowisku Babia Góra w Zabrzeży, pow. Nowy Sacz w 1963 r., Wiadomości Archeologiczne 31:2-3, p. $252-255$.

Cabalska M.

$1974 \quad Z$ badań nad problematykq najstarszej ceramiki zdobionej ornamentem guzowym $z$ terenu Polski południowej w świetle materiałów z Maszkowic, pow. Nowy Sacz, Slovenská Archeológia 22:1, p. 39-71.

Carlevaro E.

2013 Dinamiche del popolamento nell'area sudalpina dal Bronzo finale alla Chochorowski J. romanizzazione (unpublished doctoral thesis), Università di Zurigo, Zurigo.

1993 Ekspansja kimmeryjska na tereny Europy Środkowej, Kraków.

Chorąży B., Chorąży B.

2015 Struktury osadnictwa wyżynnego na przedpolu Beskidu Ślaskiego u schytku epoki brqzu i we wczesnej epoce żelaza, [in:] Pradziejowe osady obronne w Karpatach, J. Gancarski (ed.), Krosno, p. 323-345.

Czekaj-Zastawny A.

2008 Osadnictwo społeczności kultury ceramiki wstęowej rytej w dorzeczu górnej Wisty, Kraków.

Czerwiński S., Margielewski W., Gałka M., Kołaczek P.

2019 Late Holocene transformations of lower montane forest in the Beskid Wyspowy Mountains (Western Carpathians, Central Europe): a case study from Mount Mogielica, Palynology, DOI: 10.1080/01916122.2019.1617207.

Czopek S.

2005 Zur kulturgeschichtlichen Sonderstellung der polnischen Karpatenzone In der Bronze- und frühen Eisenzeit, Acta Archaeologica Carpathica 40, p. 39-61.

Czopek S., Kadrow S.

2001 Archeologia polskich Karpat a niektóre problemy neolitu i wczesnej epoki brazu, [in:] Neolit i poczatki epoki brazu w Karpatach polskich, J. Gancarski (ed.),

Čaplovič P. Krosno, p. 327-342.

1962 Najnowsze badania archeologiczne na Orawie Stowackiej, Acta Archaeologica Carpathica 4, p. 231-254.

Della Casa Ph.

2000 Mesolcina praehistorica. Mensch und Naturraum in einem Bündner-Südalpental vom Mesolithikum bis in römische Zeit, Universitätsforschungen zur prähistorischen Archäologie, vol. 67, Bonn.

Della Casa Ph.

2007 Transalpine pass routes in the Swiss Central Alps and the strategic use of topographic resources, Preistoria Alpina 42, p. 109-118. 
Della Casa Ph, Walsh K.

2007 Introduction: Interpretation of sites and material culture from mid-high altitude mountain environments, Preistoria Alpina 42, p. 5-8.

Earle T., Ling J., Unhér C., Stos-Gale Z., Melheim L.

2015 The Political Economy and Metal Trade in Bronze Age Europe: Understanding Regional Variability in Terms of Comparative Advantages and Articulations, European Journal of Archaeology 18:4, p. 633-657.

Geddes D. S.

1983 Neolithic transhumance in the Mediterranean Pyrenees, World Archaeology 15:1, p. 51-66.

Gedl M.

1982 Periodyzacja i chronologia kultury tużyckiej w zachodniej Małopolsce, [in:] Południowa strefa kultury tużyckiej i powiazania tej kultury z południem, M. Gedl (ed.), Kraków-Przemyśl, p. 11-33.

Gedl M.

1998 Młodsza epoka brazu we wschodniej części polskich Karpat, Kraków.

Gedl M.

2003 Poczattki kultury tużyckiej w zachodniej części polskich Karpat, [in:] Epoka brazu i wczesna epoka żelaza w Karpatach polskich, J. Gancarski (ed.), Krosno, p. 379-395.

Groenman-van Waateringe W., van Geel B.

2017 Raised bed agriculture in northwest Europe triggered by climatic change around 850 BC: a hypothesis, Environmental Archaeology 22:2, p. 166-170.

Haas J. N., Richoz I., Tinner W., Wick L.

1998 Synchronous Holocene climatic oscillations recorded on the Swiss Plateau and at timberline in the Alps, The Holocene 8:3, p. 301-309.

Hajnalová E.

1996 Archeobotanické a archeologické pramene $k$ rekonštrukcii lesnej vegetácie $v$ Popradskej Kotline, Slovenská Archeológia 44:2, p. 265-286.

Horváth T., Svingor É.

2015 The spatial and chronological distribution of the so-called "Baden culture", [in:] The Baden culture around the Western Carpathians, M. Nowak, A. Zastawny (eds), Via archaeologica: źródła z badań wykopaliskowych na trasie autostrady A4 w Małopolsce, vol. 12, Kraków, p. 19-75.

Jacomet S.

2006 Plant economy of the northern Alpine lake dwellings - 3500-2400 cal. BC, Environmental Archaeology 11:1, p. 65-85.

Javorský F.

1983 Výskumy a prieskumy výskumnej expedície Spiš Archeologického ústavu SAV, AVANS v roku 1982, p. 99-124.

Jędrysik J.

2018 Babia Góra w Zabrzeży odkryta na nowo, czyli grodziska średniowiecznego tutaj nie byto, Płaj 56, p. 83-93.

Jędrysik J., Rydzewska E., Markiewicz J. A., Rzońca J.

in print Rezultaty analiz chronologiczno-przestrzennych materiatów $z$ dawnych badań prehistorycznej osady wyżynnej w Zabrzeży, pow. nowosqdecki, [in:] Epoka brazu $i$ wczesna epoka żelaza $w$ Karpatach, Krosno, in print.

Jodłowski A.

1988 Badania osady wielokulturowej w Starym Sqczu na stanowisku I, Badania 
archeologiczne prowadzone przez Muzeum Żup Krakowskich Wieliczka w latach 1986-1987, p. 5-13.

Kaczanowska M. (ed.)

2006 Dziedzictwo cywilizacji naddunajskich: Małopolska na przełomie epoki kamienia i miedzi, Biblioteka Muzeum Archeologicznego w Krakowie, vol. 1, Kraków.

Kadrow S., Machnik J.

1997 Kultura mierzanowicka. Chronologia, taksonomia i rozwój przestrzenny, Prace Komisji Archeologicznej, vol. 29, Kraków.

Kamieńska J., Kozłowski J. K.

1990 Entwicklung und Gliederung der Lengyel- und Polgár-Kulturgruppen in Polen, Zeszyty Naukowe Uniwersytetu Jagiellońskiego, vol. 925, Prace Archeologiczne, vol. 46, Kraków.

Kienlin T. L., Cappenberg K., Korczyńska M. M., Przybyła M. S., Valde-Nowak P.

2011 Peripherie oder Kommunikationsraum? Siedlungsarchäologische Untersuchungen im Vorfeld der polnischen Westkarpaten (Wiśnicz-Hügelland und mittleres Dunajectal, Kleinpolen), [in:] Siedlung und Handwerk - Studien zu sozialen Kontexten in der Bronzezeit, B. Horejs, T. L. Kienlin (eds), Universitätsforschungen zur prähistorischen Archäologie, vol. 194, Bonn, p. 191-268.

Kienlin T. L., Korczyńska M. M., Cappenberg K.

2014 Alternative Trajectories in Bronze Age Landscapes and the 'Failure' to Enclose, [in:] Settlement, Communication and Exchange around the Western Carpathians, T. L. Kienlin, P. Valde-Nowak, M. Korczyńska, K. Cappenberg, J. Ociepka (eds), Oxford, p. 159-200.

Kołodziejski S., Parczewski M., Rydlewski J., Valde-Nowak P.

1982 Dzieje osadnictwa w Pieninach od czasów najdawniejszych do połowy XIV wieku, [in:] Przyroda Pienin w obliczu zmian, K. Zarzycki (ed.), Warszawa-Kraków, p. 403-421.

Koperowa W.

1961 Późnoglacjalna i holoceńska historia roślinności Kotliny Nowotarskiej, Acta Palaeobotanica 2:3, p. 3-57.

Korczyńska M., Przybyła M. S.

2020 Chronology of the Bronze and Early Iron Age in the Dunajec river valley, [in:] Inheritance, social network or local adaptation? Bronze and Early Iron Age societies in western Małopolska, K. Dzięgielewski, A. Gawlik, M. Korczyńska, M. Mazur, M. S. Przybyła (eds), Kraków, in print.

Korzeń K.

2017 Profil pytkowy z osadu torfowiskowego w Zbludzy. Rekonstrukcja rozwoju szaty roślinnej w otoczeniu Kotliny Łackiej, http://www.gora-zyndrama.archeo.uj.edu. pl/metody-i-aktualne-badania/badania-palinologiczne (Access: 3.02.2020).

Kostrzewski J.

1964 Skarby $i$ luźne znaleziska metalowe od eneolitu do wczesnego okresu żelaza $z$ górnego $i$ środkowego dorzecza Wisty $i$ górnego dorzecza Warty, Przegląd Archeologiczny 15, p. 5-133.

Krause R.

2007 The prehistoric settlement of the inneralpine valley of Montafon in Vorarlberg (Austria), Preistoria Alpina 42, p. 119-136.

Krause R., Würfel F.

2015 Die bronzezeitliche Burg am Bartholomäberg im Kontext der prähistorischen 
Besiedlung der Tallandschaft des Montafon, [in:] Archäologie in Vorarlberg, A. Rudigier, G. Grabher (eds), Vorarlberg Museum Schriften, vol. 15, Vorarlberg, p. 39-48.

Kruk J.

1980 Gospodarka $w$ Polsce potudniowo-wschodniej $w$ V-III tysiacleciu p.n.e., Wrocław.

Kruk J.

1981 Uwagi o rolnictwie neolitycznym w dorzeczu górnej Wisty, Acta Archaeologica Carpathica 21, p. 213-225.

Lech J.

1987 Z badań nad górnictwem krzemienia społeczności rolniczych Europy Środkowej. Relacje przestrzenne kopalń i osad, Acta Archaeologica Carpathica 26, p. 93-137.

Machnik J.

2001 Kultura ceramiki sznurowej $w$ strefie karpackiej (stan i perspektywy badawcze), [in:] Neolit i poczqtki epoki brqzu w Karpatach polskich, J. Gancarski (ed.), Krosno, p. 115-137.

Machnik J., Mačala P.

2001 General Results of the Polish-Slovak Interdisciplinary Research Around the Lower Beskid Mountains, [in:] Archaeology and natural background of the Lower Beskid Mountains, Carpathians, part I, J. Machnik (ed.), Prace Komisji Prehistorii Karpat, vol. 2, Kraków, p. 7-19.

Madyda-Legutko R.

1995 Sytuacja kulturowa we wczesnej epoce żelaza na terenie polskiej części Karpat Zachodnich, [in:] Dziedzictwo kulturowe epoki brazu i wczesnej epoki żelaza na Górnym Ślasku i w Małopolsce, J. Szydłowski (ed.), Ślaskie Prace Prehistoryczne, vol. 4, Katowice, p. 241-265.

Madyda-Legutko R., Poleski J.

1995 Podegrodzie, Woiwodschaft Nowy Sqcz, Fundstelle 2 „Zamczysko”. Vorgeschichtliche Siedlung und frühmittelalterlicher Burgwall, Recherches Archéologiques de 1991 et 1992, p. 71-77.

Madyda-Legutko R., Tunia K.

1985 Podegrodzie, Woiwodschaft Nowy Sacz, Gemeinde Podegrodzie, Fundstelle 9 (Siedlung der Púchov-Kultur), Recherches Archéologiques de 1983, p. 26-28.

Madyda-Legutko R., Tunia K.

2015 Osady obronne (?) ludności kultury puchowskiej nad Dunajcem, [in:] Pradziejowe osady obronne w Karpatach, J. Gancarski (ed.), Krosno, p. 347-380.

Margielewski W.

2006 Records of the Late Glacial-Holocene Paleoenvironmental Changes In Landslide Forms and Deposits of the Beskid Makowski and Beskid Wyspowy Mts. Area (Polish Outer Carpathians), Folia Quaternaria 76, p. 5-149.

Margielewski W., Zernitskaya V.

2003 Late Glacial-Holocene Paleoenvironmental Evidence Recorded in the Hajduki Peat Bog (Beskid Średni Mts., Outer Western Carpathians), Folia Quaternaria 74, p. 57-73.

Markiewicz J. A.

2020 Rozwój osadnictwa prehistorycznego w górach Europy Środkowej - studia przypadków, [in:] Archeologia Gór. In memoriam profesor Andrzej Żaki, S. Buławka, M. Cieśla, K. Kerneder-Gubała, P. Kocańda, R. Kowalski, A. Kraszewska (eds), Warszawa, p. 93-122. 
Miroššayová E.

1987 Problematika osídlenia východného Slovenska v dobe halštatskej, Slovenská Archeológia 35:1, p. 107-164.

Miroššayová E.

1992 Osídlenie Spiša v dobe halštatskej, [in:] Ziemie polskie we wczesnej epoce żelaza $i$ ich powiqzania $z$ innymi terenami: materiały z konferencji - Rzeszów, 1720.09.1991, S. Czopek (ed.), Rzeszów, p. 133-138.

Morawski F. J. S.

1863 Sqdecczyzna, tom I, Kraków (self-published).

Moskal-del Hoyo M., Lityńska-Zając M., Korczyńska M., Cywa K., Kienlin T. L., Cappenberg K.

2015

Plants and environment: results of archaeobotanical research of the Bronze Age settlements in the Carpathian Foothills in Poland, Journal of Archaeological

Nakoinz O. Science 53, p. 426-444.

2012 Datierungskodierung und chronologische Inferenz - Techniken zum Umgang mit unscharfen chronologischen Informationen, Prähistorische Zeitschrift 87:1, p. 189-207.

Obidowicz A.

1990 Eine pollenanalytische und moorkundliche Studie zur Vegetationsgeschichte des Podhale-Gebietes (West-Karpaten), Acta Palaeobotanica 30:1-2, p. 147-219.

Obrębska-Starklowa B., Hess M., Olecki Z., Trepińska J., Kowanetz L.

1995 Klimat, [in:] Karpaty polskie. Przyroda, człowiek i jego działalność, J. Warszyńska (ed.), Kraków, p. 31-47.

Pawlikowa B.

1965 Materiaty do postglacjalnej historii roślinności Karpat Zachodnich. Torfowisko na Bryjarce, Folia Quaternaria 18, p. 1-9.

Pearce M., de Guio A.

1999 Between the mountains and the plain: an integrated metals production and circulation system in later Bronze Age north-eastern Italy, [in:] Prehistoric alpine environment, society, and economy, Ph. Della Casa (ed.), Universitätsforschungen zur prähistorischen Archäologie, vol. 55, Bonn, p. 289-293.

Pelisiak A.

2013 Man and mountains: settlement economy of Neolithic communities in the eastern

Polish Carpathians, [in:] Environment and subsistence - forty years after Janusz

Kruk’s "Settlement studies...", S. Kadrow, P. Włodarczak (eds), Studien zur Archäologie in Ostmitteleuropa/Studia nad Pradziejami Europy Środkowej, vol. 11, Rzeszów-Bonn, p. 225-244.

Petrequin P., Petrequin A.-M., Errera M., Cassen S., Croutch Ch., Dufraisse A., Gauthier E., Rossy M.

2007 Les carrières néolithiques du Mont Viso (Piémont, Italie). Chronologie et conditions d'exploitation, [in:] Actes du XIe Colloque sur les Alpes dans l'Antiquité, Champsec / Val de Bagnes / Valais-Suisse. Bulletin d'études préhistoriques et archéologiques alpines, vol. 18, Aosta, p. 167-188.

Pieta K.

1982 Die Púchov-Kultur, Studia Archaeologica Slovaka Instituti Archaeologici Academiae Scientarum Slovacae, vol. I, Nitra. 
Primas M.

1999 From fiction to facts. Current research on prehistoric human activity in the Alps, [in:] Prehistoric alpine environment, society, and economy, Ph. Della Casa (ed.), Universitätsforschungen zur prähistorischen Archäologie, vol. 55, Bonn, p. 1-10.

Przybyła M. S.

2009 Intercultural contacts in the Western Carpathian area at the turn of the 2nd and 1st millennia BC, Warszawa.

Przybyła M. S.

2016 Early Bronze Age stone architecture discovered in the Polish Carpathians, Archäologisches Korrespondenzblatt 46:3, p. 291-308.

Przybyła M. S.

2020 Trends in local pottery development in the Bronze and Early Iron Age middle Dunajec river valley (test area 4), [in:] Inheritance, social network or local adaptation? Bronze and Early Iron Age societies in western Matopolska, K. Dzięgielewski, A. Gawlik, M. Korczyńska, M. Mazur, M. S. Przybyła (eds), Kraków, in print.

Przybyła M. S., Gocman U., Mueller-Bieniek A.

2020 Bronze and Early Iron Age subsistence economy in the middle Dunajec river valley (test area 4), [in:] Inheritance, social network or local adaptation? Bronze and Early Iron Age societies in western Małopolska, K. Dzięgielewski, A. Gawlik, M. Korczyńska, M. Mazur, M. S. Przybyła (eds), Kraków, in print.

Przybyła M. S., Jędrysik J.

2017 Recycled fortifications: the Late Bronze and Iron Age settlement in Maszkowice (Western Carpathians), [in:] Fortifications: Rise and Fall of Defended Sites In Late Bronze and Early Iron Age Of South-East Europe. Internat. Conference in Timişoara, Romania from November 11th to 13th, 2015, B. Heeb, A. Szentmiklosi, R. Krause, M. Wemhoff (eds), Berliner Beiträge zur Vor- und Frühgeschichte, vol. 21, Berlin, p. 91-106.

Przybyła M. S., Korzeń K., Moskal-del Hoyo M.

2020 Bronze and Early Iron Age landscape in the middle Dunajec river valley (test area 4): synthetic approach to the geomorphology and vegetation history, [in:] Inheritance, social network or local adaptation? Bronze and Early Iron Age societies in western Małopolska, K. Dzięgielewski, A. Gawlik, M. Korczyńska, M. Mazur, M. S. Przybyła (eds), Kraków, in print.

Przybyła M. S., Markiewicz J. A.

2020 Settlement network of the Bronze and Early Iron Age societies in the middle Dunajec river valley (test area 4), [in:] Inheritance, social network or local adaptation? Bronze and Early Iron Age societies in western Małopolska, K. Dzięgielewski, A. Gawlik, M. Korczyńska, M. Mazur, M. S. Przybyła (eds), Kraków, in print.

Przybyła M. S., Skoneczna M.

2011 The fortified settlement from the Early and Middle Bronze Age at Maszkowice, Nowy Sacz district (Western Carpathians). Preliminary results of studies conducted in the years 2009-2012, Recherches Archéologiques Nouvelle Serie 3, p. 5-66.

Przybyła M. S., Skoneczna M.

2014 The Bronze Age settlement in Maszkowice (Western Carpathians) - analyses and interpretations, [in:] Settlement, Communication and Exchange around 
the Western Carpathians, T. L. Kienlin, P. Valde-Nowak, M. Korczyńska, K. Cappenberg, J. Ociepka (eds), Oxford, p. 265-286.

Przybyła M. S., Skoneczna M., Vitoš A.

2012 Interregional Contacts or Local Adaptation? Studies on the Defensive Settlement from the Bronze and Early Iron Age in Maszkowice (Western Carpathians), [in:] Enclosed Space - Open Society. Contact and Exchange in the Context of Bronze Age Fortified Settlements in Central Europe. SAO/SPEŚ 9, M. Jaeger, J. Czebreszuk, K. P. Fischl (eds), Studien zur Archäologie in Ostmitteleuropa, vol. 9, Poznań-Bonn, p. 225-273.

Reitmeier T. (ed.)

2012 Letzte Jäger, erste Hirten. Hochalpine Archäologie in der Silvretta, Chur.

Röpke A., Krause R.

2013 High montane-subalpine soils in the Montafon Valley (Austria, northern Alps) and their link to land-use, fire and settlement history, Quaternary International 38-39, p. 178-189.

Rydlewski J.

1989 Pienińskie złoża radiolarytu $i$ ich eksploatacja $w$ epoce kamienia $i$ wczesnej epoce brazu na Podhalu, Acta Archaeologica Carpathica 28, p. 25-79.

Rydlewski J.

2009 Radiolarite aus den Pieninen-Die Topographie der Lagerstätten und ihr Abbau, Acta Archaeologica Carpathica 44, p. 171-182.

Rydzewski J.

1986 Przemiany stref zasiedlenia na wyżynach lessowych zachodniej Małopolski $w$ epoce brazu i żelaza, Archeologia Polski 31:1, p. 125-194.

Shennan S.

1999 Cost, benefit and value in the organization of early European copper production, Antiquity 73, p. 352-363.

Sherratt A. G.

1972 Socio-economic and demographic models for the Neolithic and Bronze Ages of Europe, [in:] Models in Archaeology, D. L. Clarke (ed.), London, p. 477-542.

Skiba S.

1995 Pokrywa glebowa, [in:] Karpaty polskie. Przyroda, człowiek i jego działalność, J. Warszyńska (ed.), Kraków, p. 69-76.

Soják M.

1999 Prieskumy a záchranný výskum na Spiši, Študijné Zvesti Archeologického Ústavu SAV 33, p. 5-33.

Soják M.

2000 Neolitické osídlenie Spiša, Slovenská Archeológia 48:2, p. 185-314.

Soják M.

2003 Stručne dejiny Spiša od najstaršich čias po rozhranienie letopočtov, [in:] Terra Scepusiensis. Stav badania o dejinach Spiša, R. Gładkiewicz, M. Homza (eds), Levoča-Wrocław, p. 115-144.

Soják M.

2015 Príspevok $k$ novým pravekým nálezom zo Spiša, Študijné Zvesti Archeologického Ústavu SAV 57, p. 141-166.

Tinner W., Lotter A. F., Ammann B., Conedera M., Hubschmid P., van Leeuwen J. F. N., Wehrli M.

2005 Klima und Landschaftsumgestaltung - Palynologische Hinweise zur Komplexität 
prähistorischer Mensch-Umwelt-Beziehungen, [in:] WES'04 - Wetland Economies and Societies. Proceedings of the International Conference in Zurich, 10-13 March 2004, Ph. Della Casa, M. Trachsel (eds), Collectio Archaeologica, vol. 3, Chronos-Zürich, p. 57-68.

Towpasz K., Zemanek B.

1995 Szata roślinna, [in:] Karpaty polskie. Przyroda, człowiek i jego działalność, J. Warszyńska (ed.), Kraków, p. 77-92.

Trzepacz-Cabalska M.

1959 Sprawozdanie z badań archeologicznych w Starym Saczu pow. Nowy Sqcz przeprowadzonych w latach 1956-1957, Wiadomości Archeologiczne 26:3-4, p. 176-181.

Tunia K.

1977 Archeologiczne zdjęcie terenu polskiej części dorzecza Popradu, Acta Archaeologica Carpathica 17, p. 183-206.

Tunia K.

1989 Umweltbedingtheiten der Agrar- und Viehzucht-Wirtschaft auf den gebirgigen Gebieten in der Urgeschichte. Casus der westkarpatischen spätkaiserzeitlichen Valde-Nowak P.

Biesiedlung, Acta Archaeologica Carpathica 28, p. 119-144.

1988 Etapy $i$ strefy zasiedlenia Karpat polskich $w$ neolicie $i$ na poczqtku epoki brazu, Wrocław-Warszawa-Kraków-Gdańsk-Łódź.

Valde-Nowak P.

1995 Osadnictwo wczesnorolnicze średniogórza niemieckiego, Kraków.

Valde-Nowak P.

1999 Neolithic Penetration of European Mid Mountains, Archaeologia Polona 37, p. 3-12.

Valde-Nowak P.

2009 Early farming adaptation in the Wiśnicz Foothills in the Carpathians. Settlements at Łoniowa and Żerków, Recherches Archéologiques Nouvelle Serie 1, p. 15-36.

Woźniak Z.

1962 Badania dwóch grodzisk w Podegrodziu, pow. Nowy Sacz w 1961 r., Acta Archaeologica Carpathica 4, p. 259-270.

Woźniak Z.

2004 Rola Karpat Zachodnich w okresie lateńskim, [in:] Okres lateński i rzymski w Karpatach polskich, J. Gancarski (ed.), Krosno, p. 43-70.

Żaki A.

1954 Wyniki wstepnych badań grodziska $w$ Naszacowicach, pow. Nowy Sacz, Wiadomości Archeologiczne 20:3, p. 234-251.

Żaki A.

1963 Archeologia gór i problemy archeologii karpackiej, Acta Archaeologica Carpathica 4, p. 5-75.

Żaki A.

1964 Karpacka Ekspedycja Archeologiczna w roku 1961-1963, Acta Archaeologica Carpathica 6, p. 145-148.

Żurowski J.

1927 Skarby halsztackiego okresu z doliny Dunajca, Prace i Materiały AntropologicznoArcheologiczne i Etnograficzne, vol. 4:1, Warszawa-Lublin-Kraków-ŁódźParyż-Poznań-Wilno-Zakopane, p. 3-112. 
Address of the Author

Joanna A. Markiewicz

Institute of Archaeology

Jagiellonian University in Kraków

ul. Gołębia 11

31-007 Kraków, Poland

joa.mark@gmail.com 